Portland State University

PDXScholar

\title{
The Rise of Mono-Ethnic Religious Nationalism in Myanmar and Its Impacts on the Security Situation of the South Asian Region
}

S M Anisuz Zaman

Portland State University

Follow this and additional works at: https://pdxscholar.library.pdx.edu/open_access_etds

Part of the Asian Studies Commons, Islamic Studies Commons, and the Peace and Conflict Studies Commons

Let us know how access to this document benefits you.

\section{Recommended Citation}

Zaman, S M Anisuz, "The Rise of Mono-Ethnic Religious Nationalism in Myanmar and Its Impacts on the Security Situation of the South Asian Region" (2020). Dissertations and Theses. Paper 5436.

https://doi.org/10.15760/etd.7309

This Thesis is brought to you for free and open access. It has been accepted for inclusion in Dissertations and Theses by an authorized administrator of PDXScholar. Please contact us if we can make this document more accessible: pdxscholar@pdx.edu. 
The Rise of Mono-Ethnic Religious Nationalism in Myanmar and Its Impacts on the Security Situation of the South Asian Region

by

S M Anisuz Zaman

A thesis submitted in partial fulfillment of the requirements for the degree of

Master of Science

In

Conflict Resolution

Thesis Committee:

Patricia Schechter, Chair

Vandy Kanyako

Tom Hastings

Portland State University

2020 
(C) 2020 S M Anisuz Zaman 


\section{Abstract}

In spite of the technological advancement and progress of liberalism, religion has remained an essential aspect of individual and national life in many countries. In many societies, religion has manifested elements of extremism, which ultimately perpetuates violence and destruction. This radical religious phenomenon is much predominant in the Southeast and South Asian region, including the country known as Myanmar. Myanmar has become a classic example of the religious fusion of politics and social life. The hybrid form of emerging democratic tenets, albeit under military sponsorship in Myanmar, provides a breeding ground for religious nationalism, with dire consequences for religious minorities. Buddhist nationalism in Myanmar has adopted a virulent antiMuslim narrative in particular and intolerance and hate towards the Muslim minority Rohingyas living in Rakhine state in particular. From August 2017, communal violence to date approximately 600,000 Rohingya fled Myanmar and became refugees in neighboring Bangladesh. The catastrophic humanitarian disaster that emanates through the Rohingya crisis poses a threat to regional security and therefore requires the immediate attention of the global community to stop further loss of lives and destruction. The impacts of the Rohingya conflict are not confined within the boundaries of Myanmar, but the conflict also impacts its neighboring Southeast Asian countries. This thesis emphasizes on the dangers of religious xenophobia as well as the use and explanation of faith for political and nationalistic causes. The paper also evaluates the role of Myanmar military in the socio-political and economic context to determine their involvement in setting the platform for the rise of Buddhist nationalism. The thesis argues that the culture of minority oppression and systemic discrimination against religious 
minority groups such as the Rohingya not only jeopardizes the county's democratic credentials and vision but also carries grave implications for Southeast Asia, one of the most volatile regions in the world.

Keywords: religious nationalism, Rohingya, Buddhism, violence, discrimination, ethnic cleansing, ethnic conflict, refugee, human rights. 


\section{Dedication}

I want to dedicate my thesis to my exceptionally loving wife, Taslima Zaman, who supported me throughout this process as well as in my career. Thank you for sacrificing our time together in favor of my research. I am grateful for your unconditional love and support for my studies. It has been a fantastic year for us, as we are blessed with a beautiful baby boy, Omar Zaman. Your smiles encouraged me all the way. My sincere thanks for allowing me to work on my thesis, even in difficult moments.

I want to extend a special feeling of gratitude to my loving mother, Momotaz Begum, and my late father, Sheikh Nizamuddin, whose words of encouragement pushed me to become a better version of myself. I wouldn't be here today without the support of my parents. Thank you for always instilling the idea that anything is achievable through hard work.

I would also like to dedicate my thesis to all the Rohingya population, who are undergoing unbearable sufferings. My sincere thanks to those who helped me by sharing their extraordinary life stories. 


\section{Acknowledgments}

Before arriving at Portland State University, I felt the warmth of the Conflict Resolution program. As an international student, I received all kinds of logistic and technical support that I required to enable me to settle in and embark on my studies. Heartfelt thanks go to all the professors of Conflict Resolution program for molding me as a capable conflict resolver. My sincere thanks to Dr. Patricia Schechter, who helped me to open my mind and look at issues from different perspectives. I am grateful to her for mentoring me in the best possible way. As most of Master's programs may uplift an individual, the Conflict Resolution program is genuinely inspiring its students to step out of their comfort zones, learn and become better practitioners through volunteering and studying the art of peacemaking and peacekeeping. I am grateful to all professors I have had the pleasure to learn from during this program: Dr. Harry Anastasiou, Dr. Mary Zinkin, Dr. Rachel Cunliffe, Dr. Barbara Tint, Dr. Amanda Byron, Dr. Robert Gould, and Dr. Vandy Kanyako. I have learned so much from their wisdom. I also like to convey my sincere thanks to Dr. Harry Anastasiou for his generous support and guidance to complete my thesis. I am grateful to Dr. Tom Hastings and Dr. Amanda Byron for providing me many practicum opportunities to practice my conflict resolution skills. I like to thank Dr. Vandy Kanyako, for his enormous support and encouragement to complete my thesis successfully. I am also thankful to program coordinator Aislyn Matias for her kind support, which contributed immensely to my successful completion of this thesis. 


\section{Table of Contents}

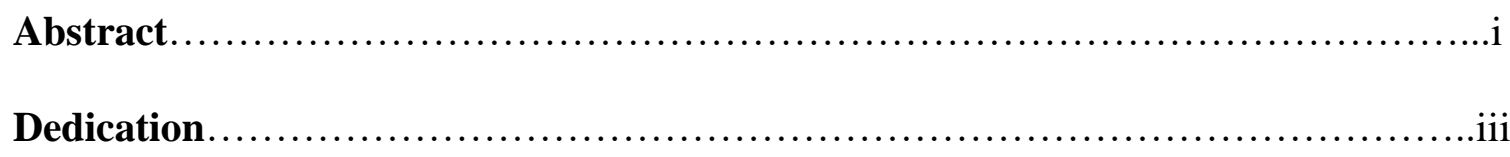

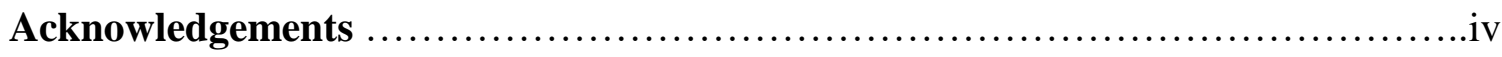

List of Abbreviations .................................................. viii

Chapter 1. Introduction......................................................

1.1 Deciding on the Topic.................................................

1.2 Research Questions..................................................5

Chapter 2. Methodology .......................................................

2.1 Thesis Design................................................. 9

Chapter 3. Literature Review......................................... 12

Chapter 4. Brief Historical Backgraound of the Myanmar Rohingya crisis........19

4.1 Facts about Myanmar................................................19

4.2 Historical Implications of the Rohingya Crisis..........................20

4.2.1 Pre-colonial Monarchy......................................21

4.2.2 Colonial Rule till Myanmar Independence.......................21

4.3 The Military Rule (1962-2011) and the militarization of Myanmar Societ...23

4.4 Present State of the Rohingya Crisis............................... 27

Chapter 5. Analysis of the Socio-Political Developments that Led to Rohingya

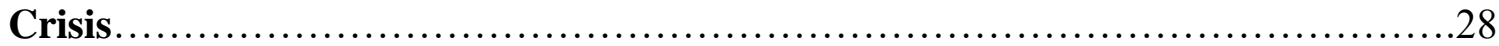

5.1 Changes that Took Place inside the Myanmar Government .................28

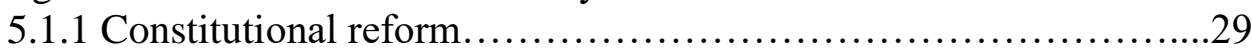

5.1.2 Institutionalization of the Military Rule ......................... 30

5.1 .3 Weakening of democratic institutions ......................... 31

5.1.4 Shifting of the capital and the Name Changes.....................33

5.2 Changes that Took Place inside Myanmar Society......................... 34

Chapter 6. Analysis of the Contexts of Rising Buddhist Nantionalism and Anti-

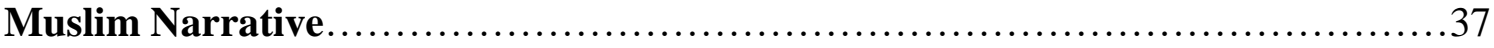

6.1 Traditional Role of Buddhism and Discrepancies from Its Teaching..........37

6.2 The Radicalization Buddhist Teaching of ............................ 38

6.3 Discrepancies of Buddhist Teaching in Myanmar.........................39

6.4 Intertwinement of Buddhist Nationalists and the Military................41 
6.5 Indications of the Rise of Buddhist Nationalism in Myanmar.

\section{Chapter 7. Analysis of Key the Divergent Experiences of the Groups and Conflict}

Supporting Narratives............................................47

7.1 Conflict Supportive Narratives ......................................47

7.2 Power Imbalance and Conflict Supporting Narratives.......................48

7.3 Experience of the Buddhist Extremists.....................................49

7.4 Experiences of Liberal Buddhists and Myanmar Civil Society.................51

7.5 Experiences of the Muslim Minority Rohingyas...........................52

\section{Chapter 8. Factors Responsible for Communal Tension between the Buddhists and}

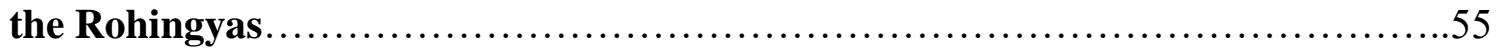

8.1 Threat to Buddhist Religious Legacy.................................55

8.2 Legislative propositions for Institutionalization of Buddhist Nationalism.

8.3 Denial of the Citizenship Rights to Rohingyas..........................58

8.4 Disparity in Economic Status....................................59

8.5 Perceived Financial Benefits for Buddhists in Anti-Rohingya Narratives

8.6 Denial of Access to Basic Amenities....................................61

8.7 Alignment of Buddhist Nationalism in State Politics of Myanmar and AntiMuslim

Narrative.

Chapter 9. Relationship between the Buddhists, the Rohingyas, Myanmar Government and the Military............................................ 66

9.1 Relationship between the Myanmar Military with the Muslim Minority

Rohingyas 66

9.2 Relationship of the Rohingyas with Myanmar Government. .69

9.3 Inter-Ethnic Relationship between Buddhists and the Rohingyas .72

9.4 Response of the Rohingyas in the Face of Mass Violence and Discrimination. 
9.5 Power Politics and Interdependency of the Military, Government and

Buddhist Nationalists.................................................76

Chapter 10. The Impacts Religious Nationalism on the Security Situations of the

South Asian Region........................................................ 80

10.1 Buddhist Extremism in Myanmar and its impacts on Neighboring

Countries.

10.2 The Influx of Rohingya Refugees and Security Threats for Bangladesh.....81

10.3 Rise of Buddhist Nationalism and Ongoing Violence in Sri Lanka..........84

10.4 The Rise of Ultra Hindu Nationalism in India..........................85

10.5 The Rise of Islamophobia in Other Neighboring Countries of Myanmar ...87

Chapter 11. Concluding Remarks and Possible Ways Forward: Recommended

Directives for Resolution................................................... 90

11.1 Concluding Remarks on Findings.................................90

11.2 Possible Ways Forward.......................................... 95

Chapter 12. Conclusion................................................ 104

Chapter 13. Implications for Conflict Resolution and Future Research............106

References.......................................................... 108

Appendix A- Interview Questionnaire.........................................114

Appendix B- IRB Approved Consent Form..................................115

Appendix C- Map of Myanmar............................................. 117

Appendix D- Map of Rakhine State.........................................118 


\section{List of Abbreviations}

\begin{tabular}{|c|c|}
\hline BIA & Burmese Independent Army \\
\hline UNDP & United Nations Development Program \\
\hline UNHRC & United Nations Human Rights Council \\
\hline SLORC & State Law and Order Restoration Council \\
\hline SPDC & State Peace and Development Council \\
\hline ARSA & Arakan Rohingya Salvation Army \\
\hline USDP & Union Solidarity and Development Party \\
\hline NLD & National League for Democracy \\
\hline USDA & Union Solidarity and Development Association \\
\hline NVC & National Verification Card \\
\hline UNHCR & United Nations High Commissioner for Refugee \\
\hline BJP & Bharatiya Janata Party \\
\hline ASEAN & Association of Southeast Nations \\
\hline SAARC & South Asian Association for Regional Cooperation \\
\hline OIC & Organization for Islamic Cooperation \\
\hline IC. & International Court of Justice \\
\hline
\end{tabular}


The Rise of Mono Ethnic Religious Nationalism in Myanmar and its Impacts on the Security Situation of the South Asian Region

\section{Chapter 1: Introduction}

\subsection{Deciding on the Topic}

In August 2017, while I was preparing to move to the USA for a Master's degree in conflict resolution, I witnessed the desperate journey of the Muslim minority Rohingyas from Myanmar to Bangladesh and other neighboring countries. It was wave after wave of hundreds of thousands of frightened people, including women, children, and the elderly, all fleeing the instability. I was watching TV news and following social media accounts, which highlighted the suffering of the Rohingyas: the mass killings, rape, the setting ablaze of houses, and eviction of people from their homeland. To learn more about the situation, I traveled to the Cox's Bazar district of Bangladesh, where refugee camps had been established by the Bangladesh government and aid agencies for the Rohingya refugees. There I heard the sad stories of the victims and their sufferings. However, this was not the first time I became a witness to such a tragic event involving the same set of people. In both 2012 and 2016, I also witnessed the forced displacement of thousands of Rohingyas from Myanmar to Bangladesh, following yet another round of communal violence. The horror stories and the sufferings recounted by the refugees caught my attention and interest. I was moved by two questions: Why are the Rohingyas unable to lead a life like other Myanmar citizens in their homeland? And why are they often the subject of violence and forced eviction? 
After moving to Portland State University, USA, to pursue my graduate degree, I regularly monitored the Myanmar Rohingya issue, which has turned out to be one of the most severe humanitarian catastrophes in the world. The spillover effects of the crisis started impacting other Southeast and South Asian countries, such as Bangladesh, India, Thailand, Sri Lanka, and Malaysia. The killing and eviction of the Muslim minority Rohingyas in Myanmar and the influx of the refugees in neighboring countries has deteriorated the security situation in the South Asian region. The recent clash between the Buddhists and the Muslims and bomb blasts in churches and hotels in Sri Lanka and the xenophobic rise of Hindu Nationalism in India should not be considered as isolated incidents. The rise of religious xenophobia in Myanmar has impacted the socio-political situations of her neighboring countries also, which made me very concerned about the further deterioration of the regional stability of the South Asian region. From my previous experience as a United Nations (UN) peacekeeper in conflict zones like Liberia, I can relate the security challenges posed by mass displacement of peoples. My recent visits to refugee camps in Bangladesh in August 2019 further affirmed my suspicion that the Rohingya issue has already turned to a severe humanitarian crisis and started posing a substantial security threat to the South Asian region as well as to global peace. The rise of communal tension will degrade human rights and social values domestically and will pose serious threats to the security and social stability of Myanmar and its neighbors. Poor socio-economic conditions in the South Asian region have created a favorable ground for the rise of religious nationalism. Religion and politics are at the heart of the crisis unfolding in this region and Myanmar in particular. 
In spite of the technological advancement and progress of liberalism, religion has remained an important aspect of individual and national life in many parts of the world. Religion not only influences personal life but also shapes the politics and culture of many nations. In some parts of the world, religion fuses with extremism, which ultimately perpetuates violence and destruction. This type of radical religious phenomenon is prevalent in the Southeast Asian region. Myanmar has become a classic example of religious fusion with politics and social life. The hybrid form of democracy under the military sponsorship in the country once knows as Burma provides a breeding ground for religious nationalism. The Buddhist nationalism in Myanmar has adopted an anti-Muslim narrative to generate intolerance and hate towards the Muslim minorities in the Rakhine state, on the western coast of Myanmar.

The UN designates the Rohingyas as 'the world's most persecuted ethnic group.' Since the start of the most recent communal violence in August 2017, approximately 600,000 Rohingya have been registered as refugees into Bangladesh (United Nations Human Rights Council, 2018). They are fleeing a high level of violence directed at them by extremists from the Buddhist majority. Such hatred and mistrust have sharply divided the Myanmar society, and the Rohingyas have become vulnerable to systematic discrimination and socio-economic exclusion, including deprivation of basic human rights, such as education, healthcare, and freedom of expression. Such a culture of minority oppression and systematic discrimination has already jeopardized the democratic vision of Myanmar. 
The impacts of the Rohingya crisis are not only confined within the boundary of Myanmar, but the conflict also continues to impact its neighboring countries. Any kind of instability caused by religious tensions in the South Asian region needs to be addressed immediately. Because due to poor socio-economic conditions, overpopulation, absence of the rule of law, and fragile social service structures, the region is not capable of dealing with a large scale humanitarian disaster over a sustained period. Also, the Myanmar incident is not an isolated incident. Therefore, there is a need to understand the global dimension of religious nationalism and communal violence in the region and other parts of the world as a whole.

In light of the above, the prevailing humanitarian crisis that emanates from the rise of Buddhist nationalism in Myanmar provides a unique opportunity for policymakers, scholars, and conflict resolution practitioners to examine and research the ongoing situations to enrich the knowledge of social studies. The study of the Rohingya crisis may help social scientists to highlight the root causes of protracted conflicts and the way forward that might be helpful for the local and international communities to support the resolution of religious conflicts around the world.

This paper focuses on the xenophobic rise in Myanmar, a country dominated by a religion often perceived as peaceful. Of equal interest to the analysis in this paper are the general characteristics of any nationalist entity and how Buddhist extremist groups in Myanmar confirm these characteristics by using religion as a tool for implementing nationalistic and political agendas. Moreover, the thesis not only focuses on the influence of religious faith in the anti-Muslim narrative but also investigates the role of the 
government and the Myanmar military in the socio-political and economic context of Myanmar. Due to the escalation of violence and massive human rights violations that have engulfed the security situation in the South Asian region, the paper further analyzes the spillover effects of the Rohingya crisis on Myanmar's neighboring countries and its ultimate impacts on the region.

The answers to the research questions posed in this thesis help to determine and eliminate the root causes of the xenophobic rise in the South Asian region, and contribute in curbing the rise of religious nationalism in the region. The study throws light on core issues that are driving the communal conflict as well as proffers solution to redressing the emerging challenges.

\subsection{Research Question}

The research question that guides the present thesis includes the following: What are the factors responsible for the rising communal tension between the Buddhist majority and the Muslim minorities in Myanmar? The research question entails several subquestions, which are:

- What internal dynamics between the Buddhists and the Rohingyas in Myanmar have played an essential role in leading to ongoing violence against the Muslim minority Rohingyas?

- What is the existing relationship between the government, the military, the Buddhists, and the Rohingyas? How has the living conditions of the Rohingyas changed between the period of democratic rule and that of the military rule? 
- What has been the traditional role of Buddhism as a peaceful religion, and has it been changed under prevailing conditions in Myanmar?

- Has the Rohingya issue become part of party politics competing for power?

- Are there any influences of existing global terrorism on the rise of xenophobia in Myanmar?

- How does the Rohingya crisis impact the security situation in the Southeast and South Asian region? To what extent has the dynamic of the relationship between the Buddhist majority and Rohingya Muslim minorities in Myanmar impacted the regional stability of South Asia?

- Is there a prospect of de-escalating the Myanmar Rohingya conflict through the actions of domestic and international actors? 


\section{Chapter 2: Methodology}

The approach of this thesis focuses on qualitative content analysis, concentrating on key 'influencers' including government officials, political leaders, academics, religious figures, the press, social media, and religious charters. At the very outset, this paper analyzes the context of the ongoing Rohingya crisis to construct an abstract outline of the inter-communal relationship in this region; successively, it focuses on the religious aspects of the conflict. I have used qualitative methodology to find the answers to questions relating to the rise of religious nationalism, and whether or not Buddhism is radicalized in Myanmar, and if so, why? Qualitative research methods are used to evaluate the historical perspectives and the present context of Myanmar in order to analyze the factors that favored the rise of religious nationalism in Myanmar. It also helps to investigate the discrepancies of Buddhist teachings with its existing practices and to identify the deviations from the traditional role of Buddhism in Myanmar society. For a comprehensive study of religious nationalism, this thesis examines three aspects of Buddhism in Myanmar. First, the level of influence Buddhism has over Myanmar society and the sources of such influences, second, when and how the traditional role of Buddhism changed to nationalist form and third, under which circumstances the Buddhist philosophy and symbols used for the idealization of Myanmar nationalism. This paper also intends to examine the role of the military in the socio-economic and political sphere of Myanmar, through analyzing the prevailing governance system, economic structure, different policies, and media reports.

Content analysis of existing literature (books, articles, journals, social media, 
news contents, and government documents) both from Myanmar and Bangladesh are also relevant sources for this academic project. The victims' perspectives have been brought out through interviews of the Rohingya communities recently moved to Portland and the Rohingyas, who had been living in Portland. To understand the prevailing sociopolitical environment of Myanmar, the essence of the lived experiences of the citizens would be useful. A series of onsite interviews conducted with the Rohingyas accommodated in the refugee camps in Bangladesh, the Border Guard members of Bangladesh, as well as the religious leaders of the Muslim and Buddhist communities living in the nearby towns of Myanmar and Bangladesh border. Interviews with the staff of various international humanitarian agencies, working in the refugee camps in Bangladesh, had been conducted to understand the present state of the Rohingyas.

The present research paper focuses on the nationalist narrative of Myanmar society under the prolonged military rule, the influence of Buddhism on the sociopolitical narrative, and how these two factors contributed to rising Buddhist nationalism in Myanmar. It examines the role of the Myanmar military in the socio-political and economic affairs, especially in relation to the Rohingya issues and the military's relationship with the Buddhist and the Muslim communities. This paper also examines the relationship between the military and the Rohingyas in order to determine if the Rohingyas are targeted for oppression and violence during the military rule only, or whether they were also subject to oppression by other regimes. Such a comparison of the living standards of the Rohingyas for the last few decades helps to understand whether or not the Rohingyas experienced a greater level of oppression, violence, and systemic 
discrimination during the successive military governments since the independence. The research paper goes further, identifying the root causes of the conflict, which gave rise to Buddhist nationalism and the anti-Muslim narrative in Myanmar. This research diagnoses the Rohingya crisis as a case study to examine the nature and extent of religious nationalism and its root causes, and impacts created over the regional security.

To understand the impacts of the xenophobic rise in Myanmar and following in Sri Lanka and India and its spillover impacts on the security situation in South Asia, the political conditions in these neighboring countries have been monitored and evaluated through analyzing the recent articles and media reports on the security situation of South Asia.

\subsection{Thesis Design}

The thesis is primarily designed to address the main research question and all the sub-questions related to it. The paper gives a brief introduction about the Rohingya crisis, followed by a factual presentation of the socio-political, economic, and religious culture of Myanmar for easy comprehension of the prevailing situation. As the Rohingya crisis is complex and linked to deep socio-political, historical, economic, and cultural roots, it is difficult to draw a specific timeline that shaped the extent of the Rohingya crisis. However, for progressive and practical research purposes, a particular timeline needs to be drawn, and the start of colonial rule in Myanmar seems to be a logical event to start with. The paper then addresses the independence movement, the first democratic rule, the rule of the oppressive military regime, and the present hybrid democratic rule in Myanmar. 
Next, a presentation on the study of the role of the Myanmar military in the socioeconomic, political, cultural, and religious aspects and the progression of the military rule in Myanmar is given. The deep-rooted influence of the military on every sphere of Myanmar society and the relationship the military maintains with the Buddhist extremists and the government is then examined. The context of interdependence between the military and the rise of religious xenophobia is analyzed to understand why and how the Buddhist nationalism flourished under strict military rule.

Later on, a presentation is given on why and how the traditional role of Buddhism in Myanmar has changed over the period and rapidly became radicalized. The study focuses on exploring the context under which Buddhism and Myanmar nationalism entwined together as a national identity that created a narrative of "Self and "Other." The paper further examines the conditions that favored the rise of nationalism, which generated much intolerance and hate that led to the violent human rights abuse of minority Rohingyas.

Finally, after discussing the aforementioned fundamental aspects of the Rohingya crisis for a complete understanding of the context of the problem, the analysis of various factors responsible for the escalation of religious nationalism is conducted and explained. The research examines the problem, analyzing the conflict supporting narratives, key divergent experiences, assertions, and the objectives of main stakeholders of the conflict. The thesis also aims to unearth the motives of transforming a peaceful religion into a violent form that used the religion to marginalize and exclude the religious minority groups and how they benefit from such motives. In the end, an assessment is given on the 
spillover impacts of the Rohingya issue on the security situation of the South Asian region. An analysis is also given confirming that the hatred and separation caused by religious nationalism have spread beyond the border of Myanmar and threatens not just the regional but also global peace. 


\section{Chapter 3: Literature Review}

To find the answer to my research question (why and how Buddhism has become radicalized so much in Myanmar and how it is impacting the domestic and the regional

peace?), I have consulted the various scholarly contents. I have found that many scholarly writings have focused on the main issue of the rising trend of religious nationalism in Myanmar and how it had been impacting the minority ethnic groups living in Myanmar. Though much research has highlighted the adverse impacts of religious nationalism, only a few researchers have analyzed and explained the root causes of religious nationalism. Among the existing literature on religious nationalism in Myanmar, very few have considered the comparison of the living conditions of the Rohingyas during different regimes. Again, only a few writers have explained the impacts of the religious nationalism on the regional and global peace. Therefore, for a comprehensive literature review, I have organized the existing scholarly literature and relevant resources into a few categories. First, I have consulted the writings of authors focusing on peace and conflict study to understand the nature and depth of the ongoing Rohingya crisis. Second, I looked for the writings of authors whose research centers on the internal dynamics of the relationship between the Buddhists and the Rohingyas. Third, I have drawn information from the scholarly papers that have explored the existing relationship between the military, government, political parties, and different ethnic minority groups in Myanmar. Fourth, I have consulted the scholarly literature that portrayed the difficult life story of the Rohingya minorities. And fifth, I have conferred the official national and international 
documents that have been published during the Rohingya crisis depicting the present humanitarian catastrophe and its impact on the regional and global peace.

In order to examine the process of transformation of peaceful religious discourses to violent forms of extremism, we need to understand the theories related to religion and nationalism. According to Friedland (2001), many cultures consider religion to be not only a guideline for religious rituals but as a complete code of life, which provides images and precepts for the society, basis for governance, and guidelines for social life. In such communities, religious influences cannot be separated from the socio-political context because of the principals and values they inject into society (Friedland, 2001). On the other hand, according to Anastasiou (2008), nationalism promotes the ideology of the state or religion as sacred, and nationalist minds consider them as uncompromised and unique (Anastasiou, 2008). In the context of Myanmar, we can see the complex fusion of religious and nationalist spirit, which finally projects through vehement discourses. It helps to conceptualize a framework for understanding the intertwinement of the religion and nationalism and direct the discovery process to identify the circumstances that favor the nourishment of religious nationalism.

To understand the fundamental aspects of the rise of religious nationalism, I have consulted the existing scholarly literature in the field of peace and conflict resolution. Those existing literature helped me to gain a holistic view under which circumstances the Rohingya conflict unfolded in Myanmar and what is the catalyst that triggered the violent situations of the conflict. Peter Alter, John Hutchinson, Anthony D. Smith, Tom Narin, Anthony Giddens, and Harry Anastasiou provided an in-depth study on the characteristics 
of nationalism and explained the factors that favor the rise of nationalism. Jonathon Fox and Mark Juergensmeyer have explicitly explored the various dimensions and indications of religious nationalism and the socio-political contributors for the rise of religious nationalism. Hannah Arendt, Tom Nardin, Evrin Stub, Erich Fromm, and Foyodor Dostoyevsky portrayed the big picture of human nature that explains how certain ideology changes and transforms in certain situations. Their analysis of the development of certain individuals and group perspectives and how the human mind responds to conflict and peace helped to look holistically towards the Rohingya crisis. Their insights and analysis help to outline the human dimensions and societal factors that create the narratives for a protracted conflict in Myanmar.

Various forces, both domestic and external, have shaped the events in Myanmar. Due to massive media censorship, the outside world had a limited scope regarding the happenings in Myanmar. Since Aung Sun Suu Kyi entered politics in 1988, what the world knew about Myanmar was all about the struggle for democracy because the media in totality highlighted her political agenda and military interferences in Myanmar politics. Thus, the minority oppression by the Buddhist nationalist movements and the military drew less media attention. The international media was mainly interested in the democratization process in Myanmar and, as such lost sight of the ethnic clashes and communal violence that ripped through the Rakhine state in particular. Buddhist nationalist uprisings were ignored at the expense of the political life and struggle of Aung Sun Suu Kyi, who became a darling of the Western press. Fink (2009), among few other analysts, became the exception as she focused on narrating and analyzing the experiences 
and thoughts of the Myanmar citizens from different spheres of life to determine their living conditions under the prolonged military rule. The author also provided an in-depth study of the psychosomatic effects of military rule on the people of Myanmar. She also highlighted the systematic abuses, corruption, and extermination by the military rulers. Fink (2009) uncovered the experiences of people living under the military rule in Myanmar and described the roles the military have taken by themselves. She also discussed the existing relationship among the government, the military, the Rohingyas, the Buddhist nationalists, and the laypeople. Yet, in her writings, Fink (2009) has covered very little about the difficult living conditions of the Rohingyas.

Jerryson and Jurgensmeyer (2010) in Buddhist Warfare, and Batholomeusz's In Defense of Dharma: Just-War Ideology in Buddhist Sri Lanka, it is shown through analysis of the conditions under which the peaceful traditional teachings of Buddhism has transformed to a violent nationalist form in present-day Myanmar. These authors contributed in creating an understanding of why and how Buddhist extremists adopted the vehement discourses, which severely disrupted the inter-ethnic communal harmony in Myanmar society. Also, the work of Gorski and Turkmen-Dervisoglu's Religion, Nationalism and Violence: An Integrated Approach and Kinnvall (2004) in her writing Globalization and Religious Nationalism: Self Identity and the Search for Ontological Security provided an in-depth analysis on the context of Buddhist nationalism in Myanmar. Such analysis helped in understanding the nationalist characteristics of Buddhism in Myanmar. Holliday (2010) outlined how Myanmar's national identity formed during the freedom movement against the British rule, which helped in 
understanding the contribution that colonial rule has on the present-day Myanmar Rohingya conflict. However, these authors have not adequately highlighted the impacts of military rule on the rising trend of religious nationalism.

Ibrahim (2016) and Zawacki (2012) have extensively engaged in addressing the historical background of the Rohingya crisis, the difficult reality the Rohingya have faced over the years, and the socio-economic and political injustice is prevailing within Myanmar society. Zawacki has narrated the oppressive and discriminatory experiences of the Rohingyas since the military rule. Ibrahim in his writing, helped to understand the challenges and barriers the Rohingyas are facing. However, their writing did not cover the difficult life situation of the liberal Buddhist society.

The national and international documents related to the citizenship law and human rights, NGO and INGO reports, the UN documents, the Kofi Anan Commission report, and the Human Rights Commission reports providing the context to understand the legal and social consequences that the Rohingyas are facing. More so, the recent articles written on the rising trend of Buddhist extremism that led to present the Rohingya issue and the violence committed against them have provided useful sources of information, which was helpful to analyze the current situation.

The current articles on the Rohingya crisis highlight the rising trends of Buddhist nationalism in the context of Myanmar. Present socio-political environment brought forward by Gravers (2013) in "Spiritual Politics, Political Religion, and Religious Freedom in Myanmar," Beech (2013) in "The Face of Buddhist Terror" and Arai in 
"Toward a Buddhist theory of Structural Peace: Lessons from Burma/Myanmar," Walton and Hayward (2014) in "Contesting Buddhist Narratives: Democratization, nationalism, and communal violence in Myanmar", which all provide thought-provoking and useful analysis of the situation. However, most of these writings have focused on the activities of the Buddhist nationalists but have not highlighted enough on the institutional influences on Buddhist nationalism.

Given its severity, not much study is specifically conducted on the Rohingya issue. Most of the studies have been undertaken from a humanitarian perspective and have identified the suffering, challenges, and deprivation of Rohingya minorities in Myanmar. However, not sufficient research has been conducted on the root causes that drive chronic violence against the Rohingyas.

The existing literature is helpful in understanding the context of communal tension in which Rohingyas are living and the continuous structured suppression they are facing. The existing writings on inter-ethnic relationships also amplified the identity issue of Rohingyas. They also describe the role the Buddhist extremists are playing in state politics, the role played by Myanmar's military in the recent situation, and the role the Myanmar government and political parties are playing in the Rohingya crisis. The existing literature helps in understanding the response of the global community on the Rohingya issue and the many debates it has spurred.

To address the Rohingya crisis, we need to understand the relational aspects of Myanmar society and Buddhist religious narrative and the role of the military in state politics. There is a lack of existing literature explaining the long-established social 
spectrum based on religion, which infused communal tension in Myanmar society and led to violence. There is a need for further study to understand the internal power dynamics of Myanmar politics and the relationship between the Buddhists, the Rohingyas, and the military in Myanmar.

Lastly, the thesis studies the religious theories and the theories of nationalism to examine how these two intertwined in Myanmar context and what are the factors that created the favorable condition for such intertwinement that gave rise to Buddhist nationalism in Myanmar and the ensuing negative backlash. 


\section{Chapter 4: Brief Historical Overview of Myanmar and the Rohingya Crisis}

\subsection{Facts about Myanmar}

Myanmar, also called Burma, is the largest country in mainland Southeast Asia with a total area of 261,970 square miles. The population is about $55,746,253$, according to the 2014 census (Asian Development Bank, 2012). In 1989, the military regime changed the country's old name 'Burma' to 'Myanmar,' and in 2006, they shifted the capital from Yangon to Nay Pyi Taw. Myanmar is surrounded by China to the north and northeast, India and Bangladesh to the west, Thailand, and Laos to the east. To the south, the country has an unbroken coastline of 1200 miles along the Bay of Bengal and the Andaman Sea. As of 2016, Myanmar ranks 145 out of 188 countries in human development according to the Human Development Index (United Nations Development Program, 2018).

Myanmar is a country of diverse ethnicity. The statistics of major ethnic groups are Bamar (Native to Myanmar)-68\%, Shan-9\%, Karen-7\%, Rakhine (Mostly Rohingya)4\%, Mon-2\%, and Other-10\% (The World Factbook, 2014). According to the Myanmar Population and Housing census 2014, Myanmar has no official language. The majority of $87.9 \%$ of people practice Theravada Buddhism, and other religious groups are Christian6.2\%, Muslim-4.3\%, Animist 0.8\%, Hindu-0.5\%, and Other-0.3\%.

The present form of government in Myanmar is a unitary parliamentary constitutional republic. As established in the 2008 constitution, the legislative power is centered around the Assembly of the Union (Pyidaungsu Hluttaw), which is a national level bicameral legislature made up of two houses; House of Nationalities (Amyotha 
Hluttaw), a 224-seat upper house and House of Representatives (Pyithu Hluttaw) a 440seat lower house. In the upper house, among 224 seats, 168 are directly elected, and 56 are appointed from Myanmar's Armed Forces. In the lower house, among 440 seats, 310 are directly elected, and 110 are appointed from Armed Forces. Therefore, Myanmar practices a hybrid form of democracy, where general people have little role to play. The House of Representatives elects the president for five years term. The president is the head of the National Defense and Security Council and enjoys the executive power of the state (Steinberg and Aung-Thwin, 2019).

Buddhism has a deep influence over almost every aspect of Myanmar society, and the majority of the people actively practice Buddhism. Buddhist religious leaders enjoy huge honor and respect in Myanmar society. Therefore, they have a strong influence on the government. Myanmar gained its independence on January 04, 1948, from the British rule. After independence, the country experienced a prolonged military rule for 51 years, which weakened the democratic system considerably.

\subsection{Historical Implications of the Rohingya Crisis}

To understand the present situation in Myanmar, and in particular, the Rohingya crisis, we need to look for the historical implications starting from the pre-colonial era. The root causes of communal disharmony and violent conflicts are linked with many significant factors that emerged during postcolonial independence, the Military rule till the present day hybrid democracy. 


\subsubsection{Pre Colonial Monarchy}

In Pre-colonial times, Burma (present Myanmar) consisted of many small kingdoms. These kingdoms thrived over a considerable period of time. Most kings adopted strategies to acquire more lands, workforce, expand the military, and build temples and palaces. Therefore, during the war campaigns, the kings used to bring thousands of captives into Burma to join their workforce. Thus, the numerous settlements of outsiders took place in Myanmar since that time, mostly from India (Fink, 2009, pp.910).

During the pre-colonial era, Buddhism secured a special place in Burman society. Most Burman kings were patrons of Buddhism and often waged war in the name of Buddhism. Once the British conquered Burma, they faced significant resistance from the Buddhist monks because the British often did not show due respect to Buddhist sacred places and teachings (Fink 2009, p. 13). Thus, during the British rule, whichever minority ethnic groups worked for the British became subject to the anguish of the Buddhists. Since then, the seeds of hatred and resentment towards the ethnic minority groups, especially the Rohingya, were planted in the minds of the Buddhist majority.

\subsubsection{Colonial Rule till Myanmar Independence}

When the British conquered most of Myanmar and established their rule in 1885, the majority of Buddhists viewed them as a predator to Buddhism as well as the cultural heritage of Myanmar. The Buddhist kings established themselves as the primary protector of Buddhism, but when the British abolished their rules, most Buddhists felt that their religious legacy was threatened in British hands. Therefore, laypeople, including monks, 
had serious resentment about the British and towards others who aided the British rule (Fink, 2019, pp.14-16). Since then, the Buddhist laypeople and religious leaders became more concerned about safeguarding their nationality and religion. During the colonial period, the tensions between the Buddhists and the Muslims surfaced in the form of the identity issue. Here, it is important to remember that the British empowered the ethnic minority groups to utilize them to support their rule, as majority Buddhists was hostile to them. That was the time when the seeds of communal disharmony were deeply planted. The mistrust and suspicion between the Buddhists and other ethnic groups were growing. However, it never became as violent as today; the Buddhist majority population maintained a sound communal harmony in Myanmar society.

With the beginning of World War Two (WW-II), the relationship between the Buddhist majority and other ethnic minorities further deteriorated, as the Buddhists were committed to fight for the Japanese. For being part of the Burma Independent Army (BIA) led by General Aung San, the Majority Buddhist communities experienced torture, ill treatment, and economic and political oppression by the British, while the ethnic minority groups, including the Rohingyas, were fighting as part of the British force. With the end of WW-II and the allied victory, the British enhanced its control over Myanmar, and the ethnic minorities were credited and rewarded with business opportunities and employment for their service to British rule. The minority groups were economically and politically uplifted by the British to accomplish their "Divide and the Rule" policy. The British also encouraged Indian and Chinese immigration, which further endangered the possibilities of communal tension (Fink, 2009, p.16). 
Due to growing pressure from the Burmese nationalist movement, the British decided to leave Myanmar, and on $4^{\text {th }}$ January 1948, Myanmar got her independence. U $\mathrm{Nu}$, a devotedly Buddhist politician, became the first prime minister of Myanmar. From independence until 1958, Myanmar experienced democratic rule, which could have significantly healed the resentment among different ethnic minority groups, and people were able to exercise their democratic rights freely (Contributor-1, Personal communication, August 29, 2019). However, in the latter part of U Nu's rule, due to his excessive devotion towards Buddhism, he favored Buddhism's to rise to the level of the unofficial state religion. Many ethnic groups, politicians, military generals, and laypeople expressed discontentment for the mismanagement of the government, and it's failure to keep the promises as mentioned in the 1947 constitution. As a result, in September 1958, a military coup was staged, and General Ne Win came to state power, which was later given the flavor of the voluntary handover of power, and a caretaker government was formed under military supervision (Fink, 2009, p.22).

\subsection{The Military Rule (1962 till 2011) and the Militarization of Myanmar Society}

In the midst of rising communal tension and amid mismanagement by the government, the military headed by General Ne Win took state power. Soon after the coup, the military gained control over most of the country by imposing tough restrictions on people's movements and limiting their civil rights. However, soon, the military started facing harder challenges regarding the market management and economic function of the country. There were shortages of essential commodities, and black-marketing was flourishing (Fink, 2009, pp.26-28). To divert people's attention from the socio-economic 
mismanagement and to enhance military control, the Junta government took the initiative to introduce a new constitution for Myanmar in 1974. The constitution was passed through a referendum, which was highly criticized for deliberate manipulation and rigging. Through the 1974 constitution, one-party rule was established, and the Junta government created seven ethnic divisions across the country with an aim to introduce a discriminatory development agenda. Thus the government was able to impose any discriminatory policies applicable to a particular state without affecting the majority Buddhist population. The non-Buddhist states were given the least priority for socioeconomic development in order to gain the support of majority Buddhists in the military's support. More so, the military conducted massive military operations in different ethnic states to suppress the demands of the minority groups. General Ne Win realized that to sustain his illegitimate rule; he should gain the confidence of majority Buddhists. Therefore, he favored the rise of Buddhist nationalism by undermining other minority religious groups.

In 1975, the military intensified their operation to curb the dominance of the Muslim minorities, which compelled about 15,000 Rohingyas to leave the country and became a refugee to Bangladesh. In 1978, a two-staged massive military operation was conducted around Sittwe, Buthidaung, and Maungdaw in Rakhine state. More than 200,000 Rohingyas left the country and became a refugee to Bangladesh to escape the military prosecution (Selth, 2018). The Junta government was not only relying on military operations; they also took steps to eliminate the Rohingyas legally. In 1982 the 
Junta promulgated new citizenship law, which stripped the citizenship rights of millions of Rohingyas.

According to the citizenship law, the Muslim minority Rohingyas were not qualified as a citizen as they were excluded from the ethnic minority lists, as stated in the law. The military promulgated this discriminatory law with deliberate planning of boosting communal tensions so that warlike situation prevails in Myanmar, which helps to justify the military rule. Without citizenship rights, the Rohingyas were denied primary healthcare, education, and political rights, and even their movements were restricted. The Rohingyas were not also incorporated in the list of 135 ethnic groups, as stated in the citizenship law (Walton \& Hayward, 2014, p.4). Therefore, without citizenship and legal recognition, the Rohingyas became subject to state-sponsored discrimination and suppression. Thus the Ne Win government planted the seeds for anti-Rohingya narratives and aimed to keep the majority Buddhist community at his side.

With the inherent inability of the military in the political and economic role, the Ne Win government collapsed in July 1988 for mismanagement of state affairs, and the Military took direct control of the power through a staged coup. The military decided to rule the country through the State Law and Order Restoration Council (SLORC). The Military continued aggressive operations in Rakhine state against the Rohingyas throughout the 1990s and later. The operation Pyi Thaya was conducted in Rakhine state to curb the growing populous dominance of the Rohingyas. During the operation, the property and business centers of the Rohingyas were confiscated, Muslims were forcibly employed in forced labor, and many were evicted from their homes and became a refugee 
to Bangladesh (Walton \& Hayward, 2014, pp.4-5). They were also barred from performing their religion freely, and many mosques were demolished. The military also imposed numerous discriminatory policies against the Rohingyas, which obstructed their access to basic human needs and undermined their fundamental human rights (Contributor-1, Personal Communication, August 29, 2019).

After coming to power, the military formed SLORC, which was subsequently renamed as State Peace and Development Council (SPDC). SPDC started ruling the country through a divide and rule policy and focused on igniting the resentment of the ethnic minority groups through a set of discriminatory policies and actions. The military aligned with the Buddhist extremist groups to gain the support of the majority Buddhist population and had been sponsoring the radical Buddhist nationalist movement $\mathrm{Ma} \mathrm{Ba}$ Tha led by Aswin Wirathu. In 2012, the Buddhist extremist groups under the banner of Ma Ba Tha called for a countrywide boycott of the Muslims. The campaigners asked people not to buy products from the Muslim shops, avoid buying their agro products and isolate them in communities (Walton \& Hayward, 2014, pp.4-5). The Buddhist extremists propagated hate speeches through rallies, meetings, leaflets, and community talks, which boosted the decades-long ongoing communal tension. In Rakhine state and some parts of other states, the Buddhist nationalists incited violence against the Muslims and killed many. Instead of protecting the minority Muslims, the military actively aided the extremists to persecute and evict the Muslims (Bookbinder, 2013). Besides the killing, huge property damage was caused for the Muslims, including the bulldozing number of mosques. Approximately 100,000 Rohingyas became homeless. 


\subsection{Present State of the Rohingya Crisis}

The recent Rohingya crisis in Myanmar in 2017 was widely condemned as ethnic cleansing due to the nature and severity of the violence that perpetrated against the Rohingyas. Since August 2017, the Myanmar military, along with Buddhist monks committing mass-scale human rights violations by killing, raping, and evicting thousands of innocent Rohingya. Myanmar military claimed that on August 25, 2017, Arakan Rohingya Salvation Army (ARSA) attacked several police check posts in Rakhine state. In retaliation to that, the military aligned with Buddhist monks conducted so-called “Clearance Operation,” which has encompassed killing many thousands of people, raped uncounted numbers of women and children, and burned most of the Rohingya villages and business centers. Approximately 800,000 Rohingya have been displaced from the northern Rakhine province of Myanmar, and they became a refugee in Bangladesh, Malaysia, Saudi Arabia, and to other neighboring countries (United Nations Human Rights Council, 2018). Two years have passed, yet their repatriation in Myanmar did not take place. Still, the Myanmar military, along with Buddhist extremists continue systematic violence against the Rohingyas in the Rakhine state. Their lands are confiscated and used for the construction of new military installations and houses for the Buddhists. The government has not taken any credible steps against the perpetrators (United Nations Human Rights Council, 2019). The international community has yet failed to take any concrete steps to make Myanmar government accountable for mass human rights violations. 


\section{Chapter 5: Analysis of the Socio-Political Developments that Led to the Rohingya Crisis}

\subsection{Changes that Took Place inside Myanmar Government}

Since the starting of the military rule in 1962 , the country has gone through many changes and amendments. The changes took place both inside the government and on the broader society. However, most of the radical changes did not take place through a democratic process. The military junta mostly brought the changes. Therefore, the hopes and aspirations of the mass of the people are not reflected in government policies and reforms. The changes in Myanmar society were intended to conform to the military rule, not to bring economic freedom; thus, the changes failed to ensure the socio-economic liberty of the people.

The 2010 election and the restoration of the parliament's function brought some hope in the minds of the freedom-loving Myanmar society. Most people hoped to see a definite shift from the decades-long military rule to a democratic process, but some people had apprehension about the actual intention of the military. The minority ethnic groups were dreaming for a better future, but the reality has been quite different. Though the military Junta formally handed over the power to a civilian authority, they decided to be the driving force and the navigator of the civilian government. With utter surprise, the people of Myanmar found the executions of Junta's policies through a civilian government. The military set the strings on the civilian government to regulate the motion of the state power. By involving the political parties in the military-led hybrid governmental system, the military could further reduce the ability of the political 
oppositions and the civil society to protest against the military government. Most government agencies and corporations received retired military officials as their head. More so, the military also maintained its significant influence in the political sphere through the Union Solidarity and Development Party (USDP), which the military formed with an aim to control the politics in Myanmar. USDP mainly consists of former military officials and their collaborators, mostly (Guilloux, 2010, pp.383-401). Considering the scope of this paper, the changes that took place inside the governmental system and in Myanmar society since 1990 are briefly discussed in the subsequent paragraphs.

\subsubsection{Constitutional reforms}

The main policy change of the government was the change of the constitution of Myanmar, which was ratified by the union of Burma in 1947. During the period of direct military rule, the military authority has changed the constitution twice. After the independence of Myanmar the military first changed the constitution in 1974. The current constitution was enacted in 2008, through a staged referendum where people's participation was very minimum. As per the current law, the legislative branch denotes to the Assembly of the Union, which is a bicameral legislature comprising of the 440 seats House of the Representatives and the 224 seats of House of Nationalities. A maximum of 56 of 224 seats in the National Assembly and 110 seats of 440 in the people's assembly are reserved for serving military members (Myanmar, 2014). The constitution was adopted through a referendum, which was highly criticized for unfairness because major political parties were not welcomed to contribute to the conception of the constitution (Martin, 2010). The Myanmar constitution has given 
legitimacy to robust military control over the civilian government. The serving military generals always hold influential ministries like the Ministry of Borders, Ministry of Defense, Ministry of Home Affairs, and Ministry of the Office of the Union Government. Another contentious issue in the constitution is the citizenship rights of the Muslim minority Rohingyas. This decision has affected the lives of Rohingyas living in Myanmar. The Muslim community has been systematically excluded from the rights and privileges of citizens. The citizenship rights of the Rohingyas are denied through the constitution, and their voting rights are also rejected. They became legally marginalized in the society, subject to all sorts of discrimination and oppression, and vulnerable to intimidating legal action.

\subsubsection{Institutionalization of military rule}

Since the beginning of the military rule, the only crisis Myanmar military faced was the legitimization of their existence in state power both internally and externally. Myanmar civil society often tried to protest the military rule in many forms, but it was mainly the students and the monks who could openly protest against the military government. The student protest happened countrywide in August 1988, and they were protesting the economic mismanagement, corruption, police brutality, and human rights violations by the Junta. The Buddhist monks led another significant movement in October 2007, popularly known as the "Saffron Movement." The "Saffron Movement" was a sequence of socio-economic and political dissents and protests against the Myanmar military Junta. However, both the revolutionary movements were cracked down by the military with violent force that resulted in thousands of deaths and 
indiscriminate arrests and detentions (Fink, 2009, pp.354-370). The international community and the UN imposed numerous sanctions to compel the Myanmar government to comply with the human rights standards (Human Rights Watch, 2014).

In light of the above situation, the Myanmar military opted out for a narrative that was based on religious connotation and capable of mobilizing mass people in their favor in the name of combating the threat against their religious legacy and national sovereignty. Though realistically, Myanmar was not vulnerable to any external aggression, and their religious legacy was not threatened.

\subsubsection{Weakening of democratic institutions}

In 1991 the military government focused on four objectives to consolidate the military rule for an infinite period (Fink 2009, p.70). First, they decided to increase the size of the armed forces to enhance their strength against the ethnic armed militia and the political rivals. Accordingly, massive recruitment took place in the military, and the strength of the armed forces was increased from 180,000 to 300,000 by the next two years (Fink, 2009, p.70). New military bases were constructed throughout the country so that troops can be readily available in every part of the country to tackle any movement against the military government.

Second, the military government adopted the strategy to breakdown the organizational setup of all the democratic entities in Myanmar. As a result, the local authorities used a variety of methods to put pressure on the National League for Democracy (NLD) members to resign (Fink 2009, p.70). In order to understand the 
rationality of the military's such approach, it is necessary to realize what kinds of insecurity the military perceives. The military's perceived insecurity is based on the fear of being held accountable for their past offenses and human rights violations in case the regime is ousted from state power in the face of a popular uprising. Therefore, it can be anticipated that the military will take any steps necessary to eliminate any threat they perceive towards the power status.

Third, the regime took the initiative to eliminate the ethnic armed struggles by forcing the ethnic armed groups to sign ceasefire agreements. The ceasefire agreement proved successful, and the military had greater access to ethnic nationality areas. But they have not signed the ceasefire agreement with the ARSA in Rakhine state where the military was fully in control of the situation and heavily engaged in a crackdown operation against the Rohingya minorities (Fink 2009, pp70-73). It is presumed that as the proposal for the ceasefire agreement came from the armed groups operating in the north of Myanmar, the government has not denied it because the denial of such a proposal would critically undermine the government's so-called willingness for the peace. Instead the military utilized the ceasefire with all armed groups except ARSA as an opportunity to strengthen their positions in the northern sector.

Fourth, the SLORC decided to adopt the open market economy to uplift the economic condition by lifting the restrictions from trade and foreign investment. However, the problem was the lack of expertise of the military to oversee the economic policies. Again, the military leadership was unwilling to employ expert economists for economic reform. Thus the generals with their self-proclaimed expertise initiated the 
economic reform. As a result, with an initial flame of development in the early 1990s, the country mostly suffered from the decreasing foreign investment, a serious diminution of the foreign reserve, and rampant inflation (Fink 2009, pp.71-74). It can be easily assumed that these financial conditions might often have encouraged the military Junta to adopt some narratives to divert the attention of the people from the ongoing economic crisis. The famous Saffron Movement took place due to financial mismanagement by the military government.

\subsubsection{Shifting the capital and name changes}

The military government also decided to give a new name for the country. So they choose 'Myanmar' as the new name for Burma. They also renamed the capital from "Rangoon" to "Yangon" in 1989, stating that those old names were associated with the colonial age. Without considering the historical and cultural connotations, the military regime moved the capital from Yangon to Nay Pyi Taw. The people's opinions were not considered while changing of country's name and shifting the capital to a new location (Houtman, 1999, pp. 43-54). The people thus widely suspected that the military shifted the capital to undermine the support structure of the political parties surrounding the old capital and to consolidate military control over the new capital. Masses of people protested on the street of Yangon against the name change of the country, but the government remained adamant in their decision (Houtman, 1999, pp. 43-54).

Though the name changes do have some religious significance, many Myanmar citizens believe that the issue is more political as most of the revolutionary scripts and 
slogans are associated with the old name "Burma." However, the change of the capital was much beneficial for the military, as they wanted the capital to be free from the political crowd. The military initiated a rumor that the US might intervene in Myanmar at any moment. Therefore, to protect the government machinery from the intervention, the capital needs to be shifted to an inaccessible location. Now, the new capital is surrounded by military installations. In the present capital, the population is four times the size of London with only 924,608 people and cost about \$ 4 billion in US dollars (Millington, 2017). The new capital is planned, executed, and financially managed by the military government. The people of Myanmar were compelled to accept the government's decision for security issues, but they saw this change as the military effort to consolidate the state power for the military rule (Contributor-2, Personal Communication, August 30, 2019). The security issues often brought up by the military overshadowed the democratic vision of Myanmar society, which in turn further entrenched and reinforced the power of the military and consequently made it more of an authoritarian regime.

\subsection{Changes that Took Place in Myanmar Society}

People of Myanmar have also experienced many changes in society during the military rule. The societal values have shifted from moralistic to materialistic. People carry the values of democracy, social justice, and equality, but over the years, when they have found it difficult to express such values and the consequences of expressing such values publicly, they changed their values as a survival technique. Despite their dislike of the military regime, many parents in Myanmar society motivate their children to abide by the military restrictions and wish their children to join the military, and thus the youths 
become part of the oppressive system (Fink, 2009,pp.114-115). Under the prolonged military rule in Myanmar, people's priority has shifted from doing things that are right to do to things that are required to survive. Society is learning how to survive rather than to foster social values.

In Myanmar society, the families are closely interwoven, and parents mainly make the decision for their children's future, education, and work. Most parents today want their children to join government services as the benefits are more, and the opportunity prevails to make more money, often through corruption. The military regime systematically induced corruption in society through families. To enter any of the government positions, a high school or university graduate must have no history of antigovernment political activities. Thus, the need to foster conformity begins early from school. Parents encourage their children to join government-sponsored organizations to avoid suspicion. Since the formation of the military-sponsored political party named the Union Solidarity and Development Association (USDA) in 1993, high school and university students are expected to become members. However, ethnic minorities, like Rohingyas, have little chance to join the USDA, and they are not allowed to participate in government services (Fink 2009, pp.73-80).

In Myanmar society, ethnic minority families face similar challenges like other families. Besides, they experience discrimination in political, socio-economic, and religious contexts (Contributor 3, Personal Communication, August 30, 2019). As the successive military regimes have emphasized Myanmar culture, Myanmar history, and Buddhism as the critical pillars of Myanmar national identity, other ethnic and religious 
groups became marginalized and often subject to discrimination. Ethnic minority languages are rarely taught in schools, and their cultures are in the process of depletion (Contributor 4, Personal Communication, September 1, 2019). The situation is worst for the Rohingyas, who are denied citizenship rights. Thus they are barred to education in public schools, and government-provided health care, positions in government services, and many more opportunities. The majority of Myanmar society often remains engaged in a survival struggle, thus hardly grow any sympathy, compassion, and accommodation for minority groups. 


\section{Chapter 6: Analysis of the contexts of Rising Buddhist Nationalism and Anti- Muslim Narrative}

\subsection{Traditional Role of Buddhism and Discrepancies from Its Teaching}

Buddhism is widely known as a peaceful religion for a long time. There is no denying the fact that, like other religions, Buddhism is also accused of its violent form, but it was never like today in Myanmar. The mass human rights violations and incitement of violence by Buddhist monks in the name of religion in Myanmar portrayed Buddhism as a violent religion. The question is, when Buddhism is gaining popularity all over the world due to its peaceful and calm image, why it is becoming increasingly violent in Myanmar? What are the driving forces transforming peaceful Buddhism to a violent religion? However, it is quite evident that Buddhism has not transformed into a violent form suddenly; it has been gradually radicalized through a systemic process. There is a progressive uprising of Buddhist extremist ideology throughout the period of the Junta regime in Myanmar. The situation was not always like this. Until the decades-long military rule, both the Muslim and the Buddhist communities coexisted peacefully for centuries (Contributor-5, Personal Communication, September 1, 2019). There were many instances of communal harmony and peaceful coexistence amongst the Buddhists and the Muslims in Myanmar (Ibrahim, 2018, p. 48). However, throughout the military rule, the junta systemically planted the seeds of religious nationalism, which generated religious intolerance and mistrust among the Buddhists and the Muslims. This chapter discusses the conditions under which the peaceful Buddhist teachings were transformed in vehement discourses to propagate the anti-Muslim narrative in Myanmar. 


\subsection{The Radicalization of Buddhist Teaching in Myanmar}

It is very important for this study to trace the circumstances through which Buddhism has been radicalized in Myanmar. Unveiling the conditions that endorsed Buddhist extremist ideology in some parts of Myanmar society will help us to understand why Buddhism shifted from peaceful to violent forms and who benefits. Buddhism was aligned with state politics and turned out into the central pillar of Myanmar national identity, but it never shifted to extremism the way it shifted during the military rule. Therefore, my argument is, there must have been some favorable situation created during the military rule, which inspired the Buddhist nationalism to rise at the present level. Now, we need to examine the prevailing socio-political situation during the military rule and the role Buddhism played during that period. Another aspect we need to understand is what really signifies the rise of Buddhist nationalism in Myanmar. Both aspects are discussed in detail in the subsequent paragraphs.

Myanmar is not a monolithic nation-state; there are many ethnic groups practicing various religious beliefs in different regional contexts. Among them, Buddhism emerged as the main religion in Myanmar for centuries and became strongly linked to the country's national identity as the Buddhist kings patronized, uplifted, and safeguarded it through many centuries. Successively, the Buddhist majority reached $87 \%$ of the total population in Myanmar (Kawanami, 2009). Thereby, over time, Buddhism has been embedded with power politics and established a dominant culture and political acceptability in Myanmar. In present times, the successive governments continue to sponsor the Buddhist religious legacy over other religions. This sponsorship has 
encouraged the radical Buddhist monks to undermine other religious minority groups and thus have developed little to no empathy for minority groups. Thus, showcasing of any religious activity by minority religious groups were found by the Buddhist nationalists as religious aggression. Therefore, when the Rohingya population rose than previous years in Rakhine state, the Buddhist extremists group envisioned it as a threat to Buddhist legacy, and accordingly, they developed their anti-Muslim narrative (Walton \& Hayward, 2014, p.6).

\subsection{Discrepancies of Buddhist Teaching in Myanmar}

The question that moved me to study the religious nationalism in Myanmar was, 'why has Buddhism shifted from its traditional peaceful teaching to vehement discourses in Myanmar? After following the ongoing situation in Myanmar, it is quite evident that a significant part of the Buddhist population in Myanmar has shifted from the traditional practice of Buddhism. It is imperative to examine the conditions, which encouraged the discrepancies of conventional Buddhist teaching. There is a distinct polarization of the Buddhist community in Myanmar, the liberal Buddhists, and the radical Buddhists. The liberal Buddhists who mostly rallied around the State Sangha Maha Nayaka Committee never endorsed the initiative of the Buddhist nationalist groups (Bookbinder, 2013). For example, in 2016, the State Sangha Maha Nayaka Committee banned Ma Ba Tha for not conforming to Buddhist teaching. The Sangha rejected the activities of the '969' movement because of the discrepancies of their teaching with Buddhist teaching. Buddhist spiritual leader, the Da-Lai-Lama, also condemned the actions of '969' after the communal riot in 2012 (Fuller, 2013). Though many Buddhists, who rallied behind the 
'969' movement, viewed it as a struggle for the protection of their religious legacy and national identity, many Buddhist scholars dismissed the 969 movements as it never carried the values of Buddhist teachings. The important Buddhist teachings are to look for a deeper association of friends, family, and the whole world. Moreover, according to Buddhist ideology, every individual should work to eliminate the suffering and not cause pain for others (Arai, 2013, p.16). If we compare these teachings with the ideology expressed by the Buddhist extremists, we can easily understand how much they have shifted from the values of Buddhism.

The acts of the Buddhist extremist monks can be related with the action of Dostoyevsky's "The Grand Inquisitor," where the grand inquisitor comprehended the responsibility of the guardian of the religion in his form and did not necessarily comply with the original values (Dostoyevsky, Granett \& Hubben, 1948). In the name of safeguarding the religion the way the grand inquisitor adopted a coercive religious measure to control the people, the Buddhist nationalist monks used the religious scripture to propagate their anti-Muslim narrative.

The idea of constructing and protecting a mono-ethnic view of national identity, which includes Buddhism as a singular religious identity in Myanmar, views others who are non-Buddhist as the enemy and impure. This nationalist view created a rift in Myanmar society and generated much intolerance. By developing a narrative of identity politics that attributed to national identity based on Buddhism, the Buddhist nationalists, along with other state actors, created the anti-Muslim narrative. As a result, traditional peaceful Buddhism started to move in the direction of nationalism, which undermines 
peaceable quality for which Buddhism is traditionally known.

\subsection{Intertwinement of Buddhist Nationalists and the Military}

After investigating the incidents of recent communal violence that occurred throughout the military rule, it became more apparent that the military did not perform its desired role in protecting civilian life and property (Bookbinder, 2013). Besides, the military, on a few occasions, played a controversial role by aiding the Buddhist extremists to perpetrate violence against the Muslim minority Rohingyas (Contributor-6, Personal communication, September 2, 2019). Therefore it became clear that the military Junta patronized Buddhism to draw the support of the majority of the population for their illegitimate rule. However, after the 2007 'Saffron' movement, the military junta inclined more towards the Buddhist extremist groups led by Aswin Wirathu, who became a second voice for the military. Both 969 and Ma Ba Tha enjoyed enormous liberty and facilities in propagating their anti-Muslim narratives. The military purposefully provided resources and platforms to the Buddhist nationalists to use them as a linchpin for creating communal tension (Al-Jazeera, 2019). By patronizing the Buddhist nationalism, the military intended to achieve two things: one, to gain the popular support of the majority Buddhists, and two, to create an anarchic situation which will always help to justify the military rule as the protector of national unity. However, it is crucial to investigate how the Buddhist extremist groups became entangled deeply with the military in propagating the anti-Muslim hate campaign.

The "Saffron Movement" was the critical turning point for the military policy in 
dealing with the Buddhist majority population, as their support is a crucial component for the military rule to survive. Military action to control the "Saffron Movement" created massive resentment among the majority Buddhists (Fink, 2009, pp.102-103). According to U Gambira, a Saffron Movement activist, after the movement, the military aimed to appease the Buddhist monks and offered $\$ 3000$ to each of the prominent monks (AlJazeera, 2019), and at the same time, they inclined to Buddhist extremists groups who are less critical about military rule and who strive to gain greater influence over society through their radical view. The military found Aswin Wirathu and his radical ideology to be more in line with military strategy. Accordingly, Aswin Wirathu was uplifted and provided with the needed freedom to launch his hate campaign through the muchcriticized 969 anti-Muslim campaigns. Khin Saw Win, an activist, communal religious analyst, who described the intertwinement of Buddhist Nationalists and the Military and commented, "so the monks and the military entered into this kind of unholy alliance" (Al-Jazeera, 2019).

\subsection{Indications of the Rise of Buddhist Nationalism in Myanmar}

For many centuries till today, Buddhism enjoyed a unique position in Myanmar society, but it was never radicalized to the extent it has reached today. There had been many incidents of communal clash between Buddhists and the Muslims during the colonial and pre-colonial era, but those were less destructive, and the communal harmony was restored. For understanding the rising trend of Buddhist nationalism in Myanmar, we need to know about the following two movements of the Buddhist extremist groups: 


\subsubsection{The '969' Movement}

The '969' movement was an important campaign initiated by the Buddhist nationalists for propagating their anti-Muslim narrative. The movement was started in early 2012, and the prominent Buddhist monk Aswin Wirathu led it. The Buddhist extremists claimed that the purpose of '969' is to "create a common symbol that enables all Buddhists to pay respect to the triple gems readily: the Buddha, the Dharma (Buddhist teaching) and the Sangha (the community)" (Arai, 2013, p.12). Initiators of the movement claim that '969' signify the virtue of Buddha, Buddhist practice, and the Buddhist community (Bookbinder, 2013). The '969' movement used the symbol of the pillar constructed during the rule of prominent Buddhist king Ashoka with an aim to unify the people under his rule. However, the ultimate intention of the movement was to unite the Buddhist community centered around this symbol to promote Buddhist nationalism and thereby notwithstanding other religious minorities. Through this movement, Aswin Wirathu emerged as an important figure in Myanmar politics by virtue of his ability to mobilize people in the anti-Muslim campaign. He also spread his antiMuslim hate campaign beyond Myanmar's border, and in 2015 he addressed the Sri Lankan monks while visiting Sri Lanka. Aswin Wirathu was invited to Sri Lanka as part of the alliance created to propagate the anti-Muslim narrative (AP, 2015). The manifesto of the '969' movement was to establish Buddhist Myanmar and to curb the demographic expansion of the Muslims in the Rakhine state. The movement also called for boycotting the business centers owned by the Muslims to cripple the Muslims economically. However, the movement was deemed by many as Islamophobic and anti-Muslim for its 
hateful propaganda against the Muslims. The activists of the '969' movement distributed leaflets, stickers, banners, and DVDs among the people to propagate the anti-Muslim narrative (Bookbinder, 2013). The movement generated strong reactions both in-home and abroad for its role in inciting a communal riot in the Rakhine state in 2012.

In October 2012, the '969' campaign incited ethnic violence among the Buddhists and the Rohingyas in Meiktila, and later it spread to many other cities in Myanmar. The Buddhist nationalists lead this communal riot against the Rohingyas (Contributor-7, personal communication, September 2, 2019). Approximately 200 Rohingyas were killed, hundreds injured, many women were raped, about 3,000 houses were demolished, and 14 mosques were set ablaze (Kipgen, 2013). The security forces did not take any actions to protect the Rohingyas; instead, they aided the Buddhist extremists to perpetrate violence. Even local policemen did not stop the violence (Contributor-8, personal communication, September 2, 2019). This incident raised questions about the mutual support between the Buddhist extremists and the Myanmar military. When under strict military surveillance, people did not dare to speak freely, then how the Buddhist nationalists were allowed to propagate hate speeches through regular meetings, rallies, and leaflets. Many people also doubted that the military might have encouraged and instigated the Buddhist extremists to commit violence (Contributor-9, personal communication, September 3, 2019). It is necessary to understand the rationality of the role played by the military during the violent incident. The motive of the '969' movement has proven to be a political standpoint because while the concern over predatory practices by multinational companies may be credible, the fusion of these concerns with the 
Rohingya Muslim minorities is regarded as highly questionable and dangerous.

\subsection{2 Мa Ba Tha}

The Patriotic Association of Myanmar, widely known as Ma Ba Tha (The abbreviated Burmese form), meaning Association for the Protection of Race and Religion, was established in January 2014, from the backdrop of the '969' movement (Kyaw, 2014). Ma-Ba Tha was well known for its anti-Muslim narrative and was not endorsed by the State Sangha Maha Nayaka Committee (Gravers, 2015, p. 14). Ashwin Wirathu was a prominent figure of Ma Ba Tha, and many leading figures from the '969' movement joined with him. People suspected that as the State Sangha Maha Nayaka Committee prohibited the use of the '969' emblem for political purpose, therefore, Buddhist extremist groups founded $\mathrm{Ma} \mathrm{Ba}$ Tha as an alternative platform for the antiMuslim campaign (Walton \& Hayward, 2014, pp.14-15). Ma-Ba Tha has widespread networks and chapters all over Myanmar (Kyaw, 2014).

The most significant campaign of the organization was to draft and publicize the controversial religious bill, which was aimed to control religious conversion and interreligious marriage and enforcement of monogamy and population control measures. In 2013, the organization conducted countrywide advertisement in favor of the bill and lobbied for the bill to pass with immediate effect. According to religious law, if a nonBuddhist man marries a Buddhist woman, they need to register their intent with the local authority and will be allowed only if the local authority gives permission. The Buddhist wife will not be able to convert into the husband's religion. On the other hand, the man 
needs to convert in Buddhism in order to marry a Buddhist woman. Ma-Ba Tha was highly criticized inside and outside Myanmar for its campaign for such a discriminatory law. However, the initiatives taken by $\mathrm{Ma} \mathrm{Ba}$ Tha and their campaign patterns indicated that they were well organized, focused, and more strategic than the '969' movement in pursuing their anti-Muslim agenda (Walton \& Hayward, 2014, pp.14-15). In July 2016, State Sangha Maha Nayaka Committee, through a statement issued, disbanded Ma Ba Tha. The statement said, "Since the first to the fifth Sangha conventions of all Buddhists orders from 1980 to 2014, none had endorsed Ma Ba Tha's legitimacy or even used the term Ma Ba Tha" (Times, 2016). 


\section{Chapter 7: Analysis of the Key Divergent Experiences of the Groups and Conflict}

\section{Supporting Narratives}

\subsection{Conflict Supportive Narratives}

Societies engaged in a perverse conflict, form the conflict supportive narratives that enlighten and rationalize the conflicts. These narratives hugely contribute to pleasing the fundamental socio-psychological desires of the conflicting groups. These narratives are extremely important in an intractable conflict where human losses and sufferings lead to prolonged suffering. In a protracted conflict, supporting narratives play a vital role in flaring-up and persistence of conflicts where the use of violent means is encouraged; these vicious ways often abuse the ethical codes (Bar-Tal, Oren \& Nets, 2014, pp.662675). If we look towards the Myanmar Rohingya conflict, we can find a systematic process through which the followers of Buddhism (A peaceful religion) turned in to

murderers. The Buddhist extremist groups used the violent anti-Rohingya narrative to bring this transformation.

Conflict supportive narratives accomplish the task of magnifying the conflict, which increases the chances of a greater level of ambiguity, instability, violence, and suffering. Conflict supporting narratives also justify the destructive ways and means that are adopted by the conflicting parties against each other (Bar-Tal, Oren \& Nets, 2014, pp.662-675). Each side's narrative prepares the group to resort to violence and genocidal acts and also to sustain the abuse of the other side. Conflict supporting narratives label the violent acts as heroic acts, and the harms are termed as a greater sacrifice for their own group. Through this process, conflict supporting narratives shape the ideological 
perception of patriotic acts and greater sacrifice, which are then defined by each group form their historical and socio-political contexts. This respective ideological perception determines how the group members should process the information, which helps them to view the conflict from a similar lens, and this helps the conflict to continue (Bar-Tal, Oren \& Nets, 2014, pp.662-672).

In the case of Myanmar, the anti-Rohingya narrative initiated by the Buddhist extremist groups and the military conditioned the Myanmar society over the years. Therefore, even after practicing a peaceful religion, the majority Buddhist communities bear little sympathy for the Rohingyas, even when the Rohingyas are subject to ethnic cleansing (Contributor-10, Personal Communication, September 3, 2019). The general Buddhist population is indoctrinated to a radical form of Buddhism and largely motivated by the extremists. The Buddhist extremists unite the majority Buddhists by projecting the Rohingyas as a threat to Buddhist legacy in Myanmar.

\subsection{Power Imbalance and Conflict Supporting Narratives}

Each side's conflict supporting narratives are shaped by their status of power (Bar-Tal, Oren \& Nets, 2014, p.662). The side having more and absolute power can expand their narratives, targeting all spheres of human lives of other sides. The powerful sides are often capable of utilizing many currencies to propagate their narratives. In the case of Myanmar, the anti-Rohingya narrative stirred by the Buddhist extremists, the military, and the government could develop the anti-Rohingya narrative in a way they wanted, because they enjoy state power and social privileges. On the other hand, the sides with less power are not able to formulate their narratives and usually have fewer 
currencies to use to shape their narratives. Like in Myanmar, the Rohingyas are not having any legal status now and little sympathy from the majority population, and thus, unable to formulate their narrative with fewer social currencies. Therefore, respective conflict supporting narratives are developed differently and end up in perpetuating further power inequalities in a conflict.

\subsection{Experience of the Buddhist Extremists}

The experience of the Buddhist extremist groups is based on fear, uncertainty, and their appealing responsibility towards the religious community and the nation. After analyzing the religious scripts, sermons, interviews, and the lectures of Buddhist nationalist leaders, it appears that the Buddhist extremist groups constantly driven by the fear of losing their religious influence. Such apprehension is not inappropriate because, during the colonial rule, the Buddhist community experienced devaluation of their religion under British rule. In the pre-colonial era, Buddhism was promoted and safeguarded by the kings and rulers, but with British occupation, such a legacy of Buddhism was diminished, which was a tragic and dishonorable period for the Buddhist community. The Buddhist extremist groups feel the burden of responsibility to regain their religious legacy. The question is that the colonial rule is not prevailing now, then, why to fear? According to Buddhist extremist leader Aswin Wirathu, the global jihadist movement of the Muslims creates a fearful environment for the Buddhists in Myanmar (Thompson, 2013). The Buddhist extremists view the rise of the Rohingya population in the Rakhine state as an impediment for their quest for national purity, a Buddhist nation. 
The appealing sense of responsibility of the Buddhist extremists shaped their experiences in the Myanmar Rohingya conflict. Buddhist monks have been guiding the communities for many decades. Such inherited responsibility inspired the Buddhist nationalist leaders to lead the society in time while global peace and stability are threatened due to the rise of Islamic extremism. According to Aswin Wirathu, they feel their responsibility as a conscious citizen of Myanmar, to combat the Jihadist for the sake of the nation as well for Buddhism. However, in practical, only3.7 \% of Muslims live in Myanmar.

The experience of laypeople that followed the Buddhist extremist ideology was quite different than the experiences of their leadership. Rewards and punishment mostly constructed the experience of the followers. The majority of the followers feel that, if they do not follow the call of the Buddhist extremist leaders to save the national identity and religious legacy, probably something terrible will happen to them spiritually. Many of them consider it their moral duty to save Buddhist heritage, and therefore they are motivated to do anything for that cause. Another issue that played a vital role in shaping their experience was military rule. The Buddhist extremist followers understand that if they are at the side of military initiatives, they will be benefited economically and socially. They perceived that, when the Rohingyas are eliminated, they would be able to enjoy the property and business centers of the Rohingyas (Contributor-11, Personal Communication, September 4, 2019). The Buddhist followers, at the same time, understood the danger of noncompliance with the military or the government initiatives. Many followers, including the top leader Aswin Wirathu, have the experience of abuse 
and oppression by the military. At any point in their life, if they fail to conform to the military and government, they have to face serious consequences.

\subsection{Experiences of the Liberal Buddhists and the Civil Society in Myanmar}

One aspect of the Myanmar socio-political scenario needs to be understood that it is not only the Muslim minorities who are experiencing oppression. The liberal Buddhists, who do not conform to the radical ideology of Buddhist extremists and the military, are also experiencing oppression. The progressive Buddhist majority of people who generally constitute the civil society in Myanmar even experience a lack of freedom and constant surveillance by the military. Though the government appears to be democratic, they are tightly held with strings of military influences. People experience a lack of freedom of expression; they cannot freely express their thoughts and ideas about political, religious, or social stands. The media and press are subject to tight censorship, and any criticism about the actions or policy of the military, the government, or the Buddhist extremist groups are dealt very severely (Fink, 2009,pp.206-208). Even many journalists are killed, disappeared, or imprisoned for their news/writings on the atrocities conducted by the military and Buddhist extremist groups. Liberal Buddhists and civil society are highly frustrated because of the degradation of traditional Buddhist morality by the Buddhist extremist groups. The liberal Buddhists often get upset when they are unable to stop the extremists (Contributor 11, Personal Communication, September 4, 2019). They find themselves trapped and suffocated in a state-sponsored, systematic cycle of oppression, and are unable to come out of this vicious cycle. For a long time, they have experienced violence, abuse, discrimination, and exclusion in society and the 
burden of truth about human rights violations, which they are not able to express to the outside world.

\subsection{Experiences of the Muslim Minority Rohingyas}

The experience of the Muslim minority Rohingyas is based on systemic oppression, institutionalized discrimination, violence, and terror. When I interviewed the Rohingya refugees in the refugee camps in Bangladesh, I heard many sad stories, stories of unbearable loss, and sufferings. Most of the families of the Rohingya population have the experiences of being killed, raped, violated, injured, and evicted from their homeland (Contributor-12, Personal Communication September 4, 2019). Many members of the community whom I interviewed are yet afraid to expose their identity. They carry the deep trauma of what happened to them during the massive human rights violations by the military and the Buddhist extremists in 2017. The Rohingya community is yet to recover from such deep trauma, and they have no helpful resources to overcome from trauma.

Since 1990, the SPDC policies were aimed to reduce the presence of Muslims and their economic power in Rakhine. Therefore, SPDC adopted a series of unfair and religiously biased policies (World Directory of Minorities and Indigenous People, 2017). The lands owned by the Rohingyas were forcefully occupied in Rakhine state and handed over to Buddhists as part of a massive settlement project aiming to implant the Buddhist families within the Muslim community to gain more control over the Muslim community. The colonization project provides each Buddhist family with 4 acres of land, a pair of bulls, and a house that is often built by Rohingyas through forced or unpaid labor (World Directory of Minorities and Indigenous People, 2017). That's how the Rohingyas are 
economically crippled down through the state-sponsored discriminative legal system. The potential power base of the Rohingya minorities is the religious platform for their unification, which is systematically targeted for elimination by the military Junta, Buddhist nationalists, and the government. The religious rights of the minorities, including Rohingyas, are rigorously violated. The military forcefully bulldozed many religious and academic institutions. Even cemeteries, monuments, and holy sites are deliberately destroyed across the country (Zawacki, 2012, pp.18-23). The denial of access to education over the period kept the majority of the Rohingyas illiterate that adversely affected them economically and politically. Thereby, their effective leadership could not develop.

While talking with the Rohingyas and the international staff who are working with them, I came to know many facts about the living conditions of the Rohingyas before and after the pathetic event of 2017. It was heartbreaking to know that they are not allowed to access public education and government healthcare facilities. Every year many children in the Rohingya community grow up without having any education. Even for emergency healthcare, they need to travel to other towns, whereas the government health center is near to their home (Contributor-12, Personal Communication September 4, 2019). They are not allowed to read and write in their own language in any school in Myanmar. Even if they are allowed to study in a private school, they have to follow Burmese books and language as a learning medium. The lack of education did not allow the Rohingyas to develop credible leadership. 
The Rohingya community also faces economic suppression and exclusion. They are not allowed to join in government jobs and many business opportunities and privileges. They need to pay extra money than the Buddhists to avail of a business permit, and they need to pay more tax than the Buddhists. More so, the Rohingya businessmen need to pay enticements and illegal tolls to the military and the government officials for running their business (Contributor-13, Personal Communication September 4, 2019). Rohingyas are not only discriminated economically, but they are also barred from performing their religious rituals. They are not allowed to build new mosques as they require, and they are not allowed to celebrate religious festivals without the permission of the local authority. They cannot even marry without the consent of the local government. A Rohingya family told me that they need to pay extra money to talk to their family members living abroad. The Rohingyas cannot obtain a passport to travel overseas. They sometimes get a passport by paying huge bribes, or often they collect a false Bangladeshi passport by paying huge money to related authority (Contributor-12, Personal Communication September 4, 2019). The Rohingyas have been experiencing such difficult living conditions for many decades. 


\section{Chapter 8: Factors Responsible for Communal Tension between the Buddhists and}

\section{The Rohingyas}

Since the beginning of the military rule, many socio-economic and political factors set the stage for the ongoing ethnic conflict between the Buddhists and the Rohingyas. Often these tensions led to violent conflicts and resulted in mass human rights violations, killings, rape, and evictions. Overtly, the Myanmar Rohingya crisis labeled as ethnic, religious conflict, but in reality, the causes of the conflicts are extended far beyond that. The internal power dynamics between the parties involved in the conflict and the greed for state power attracted many vested groups into the Rohingya conflict. A detail investigation is needed from neutral perspectives to analyze each factor separately to diagnose the leading causes that are fueling the conflict supporting narratives. For a better understanding of the reasons that are responsible for the communal tension between the Buddhists and the Rohingyas, the relevant factors are discussed in subsequent paragraphs.

\subsection{Threat to Buddhist Religious Legacy}

Buddhist extremist groups have historically experienced their inclination towards state power; therefore, imagining themselves away from the power circle is quite tricky. Ironically, this aspiration for power has deviated them from the traditional peaceful teaching of Buddhism. The ambition for power entrapped the Buddhist extremist groups for exploitation by the military, and now it is hard for the monks to separate themselves from the power cycle. The Buddhist extremist groups are aware of their power to influence Myanmar society, and they believe that by utilizing this religious power, they 
are capable of driving the society towards any direction. However, they are also aware of the deep-rooted military influences in all spheres of Myanmar society. They probably understand that the military systemized the country in a way that, without their support, none can emerge as a single power, and the religious are no exception in the reality of Myanmar.

The Buddhist extremist groups ideologically view themselves as the only guardian of Myanmar society because of the historical implications of Buddhism in Myanmar. According to Myanmar demography, Buddhists are the unanimous majority, and no other religion is even near to them in number. However, it was only the Muslim rulers who have ruled some part of Myanmar, the Arakan (present Rakhine). That is the only experience the Buddhists have of being ruled by the Muslims. Therefore, when the Rohingya population in Rakhine rose above 30\%, the Buddhist extremists got concerned about the rise of Muslim minorities in Arakan, though overall, in Myanmar, Muslims are only $3.7 \%$. There is no justifiable cause for getting worried about the demographic change of the Rohingyas. What concerned them most is the emergence of Rohingyas as financial elites in the Rakhine, who own the major business centers, and overall economic conditions of Muslim Rohingyas are better than the Buddhists. The Buddhist extremists presented an easy solution to deal with the situation, which is to evict all Rohingya Muslims and acquire their businesses and wealth for Buddhists (Zawacki, 2012, pp.18-22). These served two purposes: first, reduce the Muslim population in the Rakhine state and, second, eradicate the economic disparity. 


\subsection{Legislative propositions - Institutionalization of Buddhist Nationalism}

Another significant factor that instigated the communal tension further is the legislative initiative campaigned by the Buddhist extremist groups to promulgate the "Laws for the protection of the Race and Religion" by Myanmar parliament. The law was initially drafted and propagated by the Buddhist nationalist groups like the 'Ma BA Tha' and '969', and they gathered 2.5 million signatures in favor of the law through a nationwide campaign. In June 2013, Aswin Wirathu first introduced the draft of the bill in a monk's conference in Yangoon. Later, in November 2014, the president submitted the law to the parliament (Walton, McKay \& Kyi, 2015, p.37). This law deals with religious conversion, interreligious marriage, population control, and polygamy. According to the law, Buddhist women need to seek legal permission from local authorities if they want to marry someone from another religion. If a non-Buddhist man wants to marry a Buddhist girl, then he has to convert to Buddhism. No Myanmar citizen is allowed to marry more than one woman so long as the first wife is not legally separated or dead. Anyone failing to abide by the law is subject to 10 years of imprisonment (Walton \& Hayward, 2014, p.16).

It was quite clear to many people in Myanmar that the "Laws for the protection of the Race and Religion" is a discriminatory law, which mainly targeted the Muslim minorities. Many scholars and the civil society of Myanmar viewed the law as detrimental to communal harmony. The Buddhist nationalists initiated the law to check the population boom of the Muslims in the Rakhine state. Most women organizations in Myanmar protested against the law and claimed that the bill would undermine the rights 
of women to choose their religion and husband. Many human rights organizations condemned the act because it violates the religious rights of men and women in Myanmar (Watson and Hayward, 2014, P.17). The "Laws for the protection of the Race and Religion" had created massive resentment among the Muslims minority Rohingyas as they found it discriminatory and undignified. The law contributed to further worsening the inter-communal tension in Myanmar. Myanmar Civil Society Organizations (CSO) formally complained against the law. They claimed that the law is contradictory to the Myanmar constitution, which stated, "the Union shall not discriminate any citizen of the Republic of the Union of Myanmar, based on race, birth, religion, official position, status, culture, sex and wealth" (Kayshap, 2014). However, the Buddhist extremist groups thanked the government for promulgating the "Laws for the protection of the Race and Religion." They claimed that the law was enacted to safeguard the welfare of Buddhist women and Buddhism.

The drafting of "Laws for the protection of the Race and Religion" by the Buddhist extremists and the government's initiative to pass this law cautioned Myanmar civil society and liberal Buddhists about the intertwinement of Buddhist extremists and the military-backed government. Later, such cooperation between Buddhist extremists and the government proved destructive through the incidents of mass human rights violations in 2017 and onward.

\subsection{Denial of the Citizenship Rights to Rohingyas}

Since the independence, Rohingyas were not treated on the basis of equity and 
fairness due to their religious and biotic differences. However, in the constitution of 1948, Rohingyas were treated as citizens of Myanmar. In the new constitution of 1974, their status subsequently downgraded. Finally, the citizenship act of 1982 enacted by the military junta denied citizenship rights to the Rohingyas, which rendered them stateless (Zawacki, 2012, pp.18-20). The denial of citizenship rights has taken away all the legal protection that they had in the 1947 constitution. The military junta stripped the citizenship rights with the intention of the final elimination of the Rohingyas. When their citizenship rights denied, the Rohingyas became vulnerable for exploitation, inhuman treatment, and they are unable to seek any legal protection domestically and internationally. The situations have not changed at all since the violence of 2017. According to the UN international independent Fact-Finding Mission report of 2019, "The Government of Myanmar has made no progress towards addressing the underlying structural discrimination against the Rohingya by amending the discriminatory laws, including the 1982 Citizenship Law. State policies that impose and force Rohingya to accept national verification cards (NVCs) have intensified. The Rohingya continue to perceive the NVCs with skepticism due to their history as a tool of persecution, having been used to disenfranchise and "other" them from the rest of the population (United Nations Human Rights Council, 2019). NVC is widely known as a political tout attempt of the Myanmar government to trademark the Rohingyas as outsiders in Myanmar (Contributor-14, Personal Communication, September 4, 2019).

\subsection{Disparity in Economic Status}

Throughout the British colonial era, the ethnic minority groups got more 
privileges and opportunities than the majority Buddhist population, which helped to uplift the socio-economic conditions of the ethnic groups, including the Rohingyas. Therefore, many Rohingyas in Rakhine state could acquire more wealth and establish business centers, while the Buddhists were subject to deprivation from many employment and financial opportunities. That set the foundation of economic disparity between the Buddhists and the Rohingyas. However, during the military rule, the Rohingya businessmen faced numerous challenges due to discriminatory policies, which diminished their economic solvency at greater length. Again, as the Rohingyas were not allowed to join the government services, they mostly got involved in farming, which gave them solvency and better financial condition than many Buddhists. Another significant aspect that contributed to the economic disparity between the Buddhists and the Rohingyas is the higher birth rate of the Rohingyas. Most Rohingya families have more family members than most Buddhist families. As the number of earning members in Rohingya families is more, they ultimately earn more. Buddhist extremist groups magnified the issue of this economic disparity in the Rakhine state and used it to mobilize the majority Buddhists in the anti-Muslim campaign.

The '969' movement twisted the real fact and propagated that the Rohingyas are investing their money for converting the Buddhists into Islam (Fink, 2009, pp.239-240). Also, the '969' movement urged the Buddhists to boycott the business centers owned by the Rohingyas, which crippled down the Rohingyas economically. In reality, there was no single incident of such conversion through monetary benefits; a few conversions took place only through interfaith marriage. Moreover, the Rohingya businessmen need to pay 
more taxes than the Buddhists and more undocumented illegal tolls and bride to local authorities to retain their business permit. Despite such oppressions, the Rohingya businessmen often donate to the local monastery and other religious rituals of the Buddhists (Contributor-15, Personal Communication, September 5, 2019).

\subsection{Perceived Financial Benefits for the Buddhist in Anti-Rohingya Narratives}

During recent crackdown against the Rohingyas in Rakhine, mostly the military and the Buddhist extremists' groups participated in the violence (Contributor-15, Personal Communication, September 5, 2019). The most worrying fact is that many lay people of Buddhist majority also participated in the violence. What was their motivation for such a genocidal act? The motivation lies in the anti- Rohingya narratives preached by the Buddhist extremist leaders. The first motivation they preached is that when the Muslim business centers are boycotted, then the Buddhist business centers will be able to make more profits. Their second motivation was when Rohingyas are evicted from their lands, farms, and business center; those will be allotted to Buddhist locals. Their third motivation was those who are participating in violence against Rohingyas are serving the legacy of Buddhism, and therefore they will be spiritually rewarded (Contributor-16, Personal Communication, September 5, 2019). Besides the motivational factors, some Buddhists took it as an opportunity to gain the trust and confidence of the ruling class, which they might utilize later for their gains.

\subsection{Denial of Access to Basic Amenities for the Rohingya}

Under the structured discriminatory government systems, Rohingyas are largely 
denied from many basic amenities, like education, healthcare, housing, and many other social opportunities (Contributor-17, Personal Communication, September 5, 2019). Since the beginning of military rule, the Rohingyas started facing discrimination and systemic oppression. Over time, as the military rule entrenched more and more deeply inside Myanmar society, the Rohingyas experienced a greater degree of suppression and discrimination. The Rohingya youths were denied education since the military rule. In postcolonial time, the Rohingyas had their textbooks written in native language and schools, but with the military rule, they were compelled to read the books that are written in Burmese language (Contributor-17, Personal Communication, September 5, 2019). Later in the 90s, Rohingyas are not allowed to go to a government school or university. Similarly, the Rohingyas experienced discrimination in healthcare also. They are not permitted to receive healthcare services in public healthcare centers. Even if they visit private hospitals, they need to pay more and receive abusive words and poor services. Rohingyas also face hard restrictions on their movement. They are not allowed to visit other provinces or towns. The Rohingyas cannot apply to government jobs due to discriminatory policies, though many of them had government jobs before the military rule. They need to comply with discriminatory government instructions if they want to run a business center or shop. However, the Rohingyas are not allowed to do business in other provinces, but they can do business in Rakhine state but have to pay higher taxes (Contributor-18, Personal Communication, September 6, 2019). Rohingyas also face restrictions on their marriage. They need to take permission from the local authority to get married. However, the permissions are rarely granted. 


\subsection{Alignment of Buddhist Nationalism in State Politics of Myanmar and Anti- Muslim Narrative}

As previously mentioned, Buddhism had been influencing Myanmar politics since long before the colonial era. During the British rule and Japanese occupation, the influence of Buddhism in politics was greatly diminished, but since independence in 1948 until today, each government placed higher importance on Buddhism as a key pillar to Myanmar national identity (Jurgensmeyer, 2010,pp.262-273). Most governments patronized Buddhism to keep the support of the majority Buddhist population on their side. Especially the military painted their image as the custodian of Buddhism in Myanmar by sponsoring Buddhist nationalism. Thereby Buddhism reemerged as an ideological and philosophical guardian of state politics in post-independent Burma, but the rights of the religious minority groups were undermined to a great extent (Arai, 2013). After independence, the $\mathrm{U} \mathrm{Nu}$ regime intertwined Buddhism with state politics and governance by placing Buddhism at the high status of all state affairs and, at the same time, suppressing other religious minorities. The regime allocated much of its resources for promoting Buddhism by sponsoring traditional Buddhist cultures, meditation programs, and organizing international seminars for Buddhist monks. Following the path of ancient Buddhist kings, $\mathrm{U}$ Nu proved him as a dedicated soul for Buddhism (Fink, 2009, p.21).

The priority and level of attention given to Buddhism were reflected through subsequent government policies and development agendas, which created significant resentment among the religious minority groups. The subsequent military governments after the $\mathrm{U} \mathrm{Nu}$ regime utilized these resentments to overshadow the mismanagement in 
Myanmar's socio-economic and political affairs. The military adopted the anti-Muslim narrative to depict the Muslim minority Rohingyas and other non-Buddhists as a barrier in attaining the purity of homogenous Burmese national identity, the identity that is based on Buddhism (Long, 2013, pp.79-94). The anti-Muslim narrative helped the military to keep the communal tension alive. The military found the Rohingyas most appropriate for incriminating because of two reasons: First, they allied with the British colonial power, which dehumanized the Buddhists, and second, they do not conform to Buddhism, which is viewed as a threat to Buddhist legacy in Myanmar. These two reasons helped the military and the Buddhist nationalists to develop a perception of 'Other' and inspired the majority Buddhists to disassociate them from mainstream society. This helped to create the anti-Muslim narrative and led the government, military, and the Buddhist nationalists to adopt the exclusion policy for the Rohingyas (Schober, 2011). The military's such effort planted the seeds of Buddhist nationalism, which later surfaced in violent forms and engulfed the secular democratic vision of Myanmar.

Another significant evidence that indicates government alignment with the Buddhist Nationalists is the governmental reforms throughout the military rule, which institutionalized the discrimination and oppression against the religious minority groups, especially the Rohingyas. The Interfaith Marriage act, Religious conversion law, and Polygamy law are some of such discriminatory laws. As previously mentioned that the bills for these laws were drafted by extremist entities like '969' and 'Ma Ba Tha' and then given to the government to pass through the parliament. Accordingly, the president submitted the bills to Parliament. Another evidence of the government's patronization of 
Buddhist nationalism is the immunities enjoyed by the extremist groups in propagating hate speech as part of the anti-Muslim narrative. Under the military rule, when all the political parties were subject to huge restrictions, the extremist groups conducted countrywide rallies, processions, and meetings without any hindrance (Coates, 2013, pp.1-3). Even when the Buddhist nationalists committed violence and destruction of properties against the Muslims, instead of protecting the Rohingyas, the military assisted the extremists in human rights violations. Moreover, the government often tried to protect the extremists through their official statement, for example, the minister of religious affairs denied the issues of hate speeches and claimed that those speeches are, "about promoting love and understanding between religions... It is impossible that he (i.e., Wirathu) is inciting religious violence" (Marshall, 2013).

The entire Myanmar history in the colonial period and the post-independence time is the history of nationalist's narratives that sharply divided the society through discriminatory acts against the minorities. The triangle relationship between the military, the government, and the Buddhist extremist groups facilitated the development of violent discourses for anti-Muslim narrative. Among these three entities, the military assumed the led role for excluding the Muslim minority Rohingyas, where the government and the Buddhist extremists engaged in containing the society through the magnified fear and insecurities of losing the legacy of Buddhism. At the pinnacle of such a nationalist movement, the discriminatory citizenship act was promulgated in 1982, which allowed the Buddhist extremists and the military to set the stage for ethnic cleansing. 


\section{Chapter 9: Relationship between the Buddhists, the Rohingyas, Myanmar Government, and the Military}

Throughout Myanmar's history, all the development of religious nationalism has neatly integrated the Buddhist nationalists, the government, and the military to achieve a tragic convergence. Over time, the military, the government, and the Buddhist extremists surfaced as anti- Muslim entities. In Myanmar, the prolonged military rule crippled the traditional social structure and thereby made it difficult to imagine a civil society or the government free from military influence or military integration. Over time, the military became entrenched deeply in the societal structure of Myanmar. The military, the Buddhist community, and the government combined in creating a narrative of "Us" vs. the Rohingyas while launching the anti-Rohingya campaign. Therefore, it is imperative to study the relationship of the Rohingyas with Myanmar Buddhists, government, and the military to understand the transition and development of their relationships. Therefore, in this particular section, the context of rising Buddhist nationalism and existing relationships between the different groups involved in the Rohingya crisis are examined. While discussing the relationship between the groups, the discussion will start with the relationship between the most influential groups, like the military, and the Buddhist extremist groups and then progress with the least powerful groups, like the relationship between the Rohingyas and Myanmar civil society.

\subsection{Relationship between Myanmar Military and the Muslim Minority Rohingyas}

During the Junta rule in Myanmar, all the governments have utilized the threat of a Muslim invasion to stir up Buddhist nationalist sentiment. Historically, when there are 
protests against the regime due to financial mismanagement, corruption, or the price hike of commodities, the anti-Muslim issues use to surface (Fink, 2019, p.239). The government and the military get much involved in the anti-Muslim issue, and statesponsored media focuses on the problems so that the attention of the masses is intentionally diverted from the real-life problem of Myanmar citizens. In July 1988, after student demonstration in Rangoon against the Junta regime, leaflets were unexpectedly found in the town 'Taunggyi' and other places of Myanmar where anti-military feelings were rising. The Buddhist extremist groups claimed that the leaflets were written by the Muslims to inspire fellow Muslims to marry Buddhist women (Fink, 2009, p.240). As a result, a violent Muslim-Buddhist communal riot broke out, and the business center and house owned by the Muslims were attacked and robbed. Similar kinds of leaflets appeared several times in the past, more specifically in October 1996 in Rangoon, when leaflets appeared that propagated the Muslim plans of taking over the Buddhist community. Most of the Buddhist community reacted violently after seeing the leaflets, while liberal Buddhists viewed the incident as an attempt by the Buddhist extremist groups to incite communal violence (Fink, 2009, pp.240-244). However, this incident inflicted bitterness in the relationship between the Buddhists and the Rohingyas.

It is a common perception that there are "two governments" in Myanmar, the civilian, and the military. As this is the case, it is not clear who has taken over the role of "protector of the religion," which used to be the role of the king. As the majority of the voters belong to the Buddhist community, the rulers need to convince the voters that the candidate is the right person to rule the country and to protect the religion. As Sitagu in 
his sermon is encouraging the military to go out and fight for the country and the religion, he seems to be giving this role to the military leaders (Johannessen, 2018). With this development, it could be argued that the Senior General is trying to brand himself, maybe not as a king, but as the next best thing, as Prime Minister. As the election gets closer, this can prove as good tactic for him as the military is now enjoying an enormous rise in popularity after their expulsion of the Rohingyas (Paddock, 2017). Frydenlund (2015) also suggested that the military's actions in the Rakhine state could be seen as a morbid part of a long-term electoral campaign. I also suggest that the military might be using the protectionist agenda of the $\mathrm{Ma} \mathrm{Ba}$ Tha and associated monks, and combining it with their own form of nationalism. Even if the Ma Ba Tha itself is not concerned with the nationalist aspects, the military can use the support of this organization to claim that the generals will protect the religion, as suggested by Frydenlund (2015).

In light of the above, another essential aspect of the power dynamics of the Myanmar military needs to be discussed to understand how the military impact the fate of Rohingyas. Myanmar military is the sole power of the country, and they control every aspect of citizens' life through extensive surveillance and monitoring. Myanmar military ranked 37 out of 137 countries in the world as a military power (Global Fire Power Index, 2019). Large numbers of the population are linked with military service directly or indirectly. The $25 \%$ reserve seat in the parliament allows them to steer the country's policy towards the direction they want. The military also owns and maintains huge businesses and contributes a substantial portion of the national revenue, which enhances their influence over the business community in Myanmar. More so, the military has 
business ties with many international companies, which can effectively obstruct any global initiative against the Myanmar military. Since the military rule of 1962, the Myanmar military has ruled the country for decades. They have extended their influences deeper inside all sectors, societies, economies, and politics of Myanmar. Civil society and political parties are unable to alter the fate of Myanmar towards a progressive democratic country due to prolonged military rule.

\subsection{Relationship of the Rohingyas with the Myanmar Government}

Except for the post-independence first government, the Rohingyas were subject to ill treatment by all successive governments. Since the start of the military rule until today, all the government policies promulgated against the Rohingyas have heavily impacted the Muslim minority Rohingyas. The citizenship act enacted by the military government in 1982 paved the way for the systematic elimination of Rohingyas. Along with the adoption of discriminatory citizenship law, Myanmar government also adopted the policy of "Othering" the Rohingyas through the anti-Muslim narrative. In 1989, a Myanmar national newspaper published fourteen articles titled, "we fear deracination!" that focused on the demographic threat of the Muslims to Buddhist legacy in Myanmar. The ministry of immigration and population also show a fear of others, through their use of an old colonial-era slogan: "The earth will not swallow a race of extinction but another will!" (Kyaw, 2013). Frydenlund (2015) writes of how Muslims today are portrayed as terrorists, associated with Islamic global imperialism. The connection to the perceived international global threat has conveniently taken root in local competitions for power in Myanmar (Frydenlund, 2015, p.3). Schissler, Walton, and Thi (2017) used interviews of 
Myanmar nationals to show the prejudice and mentality that exists regarding Muslims and Islam. The article explains how everyday customary actions that is dependent on an ability to see other people as monsters rationalize the practices of violence (Schissler, Walton \& Thi, 2017, p.377).

From a historical perspective also, we can see the events following the Japanese occupation cemented the divide between the Buddhists and the Rohingyas. The attempts at unifying the nation through Buddhism often saw the Rohingya portrayed as Bengalis and outsiders, and later as illegal citizens from 1948 and onward (Tonkin, 2018, pp.226237). Not recognizing Rohingya as an ethnic group in the constitution solidified the want for separatism for the Rohingya people. This decision also signals that the state sees them as illegal immigrants. Connecting the idea of separatism to Muslim terrorists abroad has alienated the Rohingya from Myanmar and given room for Muslim political and military groups (Yegar, 1972, p.97, 110-112).

In the crisis in Rakhine State, the act of "alienation" is twofold. On the one hand, it separates the Rohingya Muslims from the Rakhine Buddhists, and on the other, it groups all Muslims together (Schonthal, 2016, p.238). Schonthal (2016) refers to the "Muslim-Buddhist" framing of the conflict, writing that "the recent violence is interpreted not as much as a conflict between certain communities of Buddhists and Muslims, but between Buddhist and Muslims writ large, or between Buddhism and Islam” (Schonthal, 2016, p.238). 
It is pertinent to discuss the existing power dynamics of the Myanmar government in the context of the Rohingya crisis. The Myanmar government can be compared with a parasite (an organism that lives on the surface of another living organism), which relies on others for their survival. The leading political parties are controlled by rules and regulations promulgated by the military Junta. The civilian government aimed to move to democracy since 2011, but in reality, the form of government introduced by the military junta is a mixed dictatorship. The military ensured fixing strings on the government so that they could effectively control the country's political and economic power. While the government alignment with the military makes them a powerful entity in Myanmar, it is evident that the government is unable to act independently, and they appear powerless without the support of the military.

As the government and the military share common ideological approaches towards the Rohingya minorities, they both maintain the mutual responsibility towards each other to accomplish the goals in marginalizing the Rohingyas. Aung San Suu Kyi, a Noble Lauriat and the leader of NLD, is a prominent figure in Myanmar politics but became a puppet of the Myanmar military. She advocated for the military during the ongoing Rohingya genocide in 2017 , which diminished her image as a democratic leader. It is a fact that the political parties in Myanmar became handicapped due to military intimidation and control.

In the end, it is necessary to mention that distinct power inequality prevails among the Buddhist nationalists, and the ruling class who are driving the anti-Muslim narrative, and the Rohingyas are the victim of such narrative. The military, government, and 
Buddhist extremist groups maintain a classical power-sharing relationship and can exercise their power to create any narrative in any form that suits their interests and makes that narrative believable (Foucault, 1978). In the present context of Myanmar hybrid democratic system, the Buddhist extremist groups who have the support of the military and the government enjoy more power and freedom than the Muslim minority, Rohingyas, who are bounded with strict restrictions and constantly dehumanized (Contributor-18, Personal Communication September 6, 2019). This ongoing phenomenon of power inequality established the right of the Buddhist extremist groups to suppress and annihilate the less powerful Rohingyas, followed by ethnic cleansing.

\subsection{Inter-Ethnic Relationship between Buddhists and the Rohingyas}

In Myanmar, the Buddhists and the Muslim minority Rohingyas have coexisted together for many decades. There were few incidents of the communal clash between the Buddhists and the Muslims in different junctures of Myanmar history, but overall, both religious groups lived in communal harmony during most of the period of their account until recent tension (Thompson, 2013). Even after independence, the Muslim community was free to practice their religion and allowed to access all the benefits like other citizens. In the post-independence socio-economic context, both the communities lived peacefully. The post-independent new government paved the way for the peaceful coexistence of majority and minority communities through the first constitution. However, such peaceful coexistence was disrupted as the military took over the state power. Since the first military coup in 1958, the rift has continued between the two ethnic groups. The military played a key role in propagating the anti-Rohingya narrative. As the military leadership 
created a roadmap for the continuation of military rule for a prolonged period, they adopted the 'Divide and Rule' policy by propagating religious tensions between the Buddhists and the Rohingyas. The military aimed to keep the communal tension alive so that they could justify their presence in national politics and state power.

Despite the rise of religious nationalism in Myanmar, liberal Buddhist communities also existed in Myanmar society. On many occasions, through press briefing, protest, and community dialogue, these Buddhist liberal groups oppose the nationalistic views of Buddhist extremist monks and the military. The liberal Buddhist groups prefer to practice the traditional role of Buddhism, and they are not in favor of being part of the state power cycle. According to U Gambira, a Saffron movement activist, the majority of Buddhist people are eager to perform their monastic role and social responsibilities and less interested in politics (Al-Jazeera, 2019). The liberal Buddhists prefer to adopt the nonviolent approach, and the Saffron revolution is a classic example of that. Though some liberal Buddhists might have some resentment on the Rohingyas (for the role the Rohingyas played during colonial age), they never support the exclusion policy for the Rohingyas (Ibrahim, 2016, p.70). Based on the actual teaching of Buddha, the liberal Buddhists want to coexist peacefully with other people living in Myanmar. The liberal Buddhists are aware of the rise of Buddhist extremism in Myanmar. They are not happy about the falsification of the Buddhist scripture by Buddhist extremists to adopt violence (Contributor-11, Personal Communication, September 4, 2019). However, they are not able to oppose it forcefully due to the military and government's alignment with Buddhist extremist groups. 
Due to the nationalist propaganda of the Buddhist extremists, there is hardly any sympathy for the sufferings of the Rohingyas among the local Buddhists in Rakhines and other parts of Myanmar (Fink 2009, p.241). The military junta has been successful so far in creating a rift between different ethnic groups and in maintaining a warlike situation in Myanmar. The military junta systematically infused much intolerance and mistrust among the Buddhist majority and the Muslim minorities to promote communal tension.

Buddhist nationalism seems to merge with, or present itself as, Myanmar nationalism. The rise of Buddhist nationalism greatly influences the relationship of Buddhists with the Rohingyas because, through Ma Ba Tha, the Buddhist extremists present Buddhism as an integral part of Myanmar nationalism. It is essential to understand how the Buddhist extremists construct the Muslim "Other" in Myanmar, which helps to understand the total gamut of the Rohingya conflict. In light of the narrative mentioned above and facts, it can be concluded that the Muslims who are different from the Buddhists/Burmese "Us" are seen as inherently violent and a threat to the peace of the country. Islam is also portrayed as a conquering religion, aiming to destroy Buddhism in Myanmar. Muslims are described as less than human, and any violent actions against them are, therefore, not an unwholesome act for the protection of the country and the religion. Violence is presented as a reasonable and necessary response to this threat. This ideology is preached directly by Sitagu to support the military actions against the Rohingyas, while Wirathu shows the need for violent acts indirectly to the Burmese Buddhist people (Gravers, 2015, pp.14-15). 


\subsection{Response of the Rohingyas in the face of mass violence and discrimination}

Despite the difficult living conditions of the Muslim minority Rohingyas in Myanmar, they have not resorted to violent means or counter attacked the Buddhist nationalist movement to safeguard their rights. The only resistance surfacing in the name of Rohingya is the armed movement of the Arakan Rohingya Salvation Army (ARSA). They have a bare minimum number of members and weapons and do not have any significant connection or support from the greater Rohingya community (Contributor-12, Personal Communication, September 4, 2019). In fact, since the military rule, the Rohingyas are actually living under constant fear of the military brutality and media censorship, they were unable to build any non-violent campaign for the resistance against the Junta regime (Contributor 12, Personal Communication, September 4, 2019). Moreover, due to the government-imposed restrictions on the movements and the denial of freedom of speech and political rights, they found it difficult to organize any social or political movement to voice their demands or protest against the oppression and discrimination. As a result of the factors mentioned above, the Rohingyas still could not develop any credible political platform or leadership to raise their voices locally or internationally about the violence, discrimination, and denial they are facing over the years.

In light of the above, to understand the interethnic relationship of the Rohingyas with the rest of Myanmar societies, it is imperative to study the existing power dynamics of the Rohingyas, the Buddhist extremist groups and Myanmar civil society, which are discussed in subsequent paragraphs. 


\subsection{Power Politics and Interdependency of the Military, Government and Buddhist Nationalists}

If we create an index of the power status of stakeholders in Myanmar Rohingya conflict, we can find that the Military will rank 1st, Buddhist extremist groups in $2^{\text {nd }}$, Myanmar government will rank $3^{\text {rd }}$, and the civil society at the $4^{\text {th }}$ position. Though the power differences exist between groups involved in the Rohingya conflict, there also prevails mutual power interdependence between a few groups, like the Myanmar government, the military, and the Buddhist extremist groups. The military Junta and the Buddhist extremist groups both works for the same goal because the military supports the Buddhist extremist groups to accomplish their ultimate goal of staying in power. The Buddhist extremist groups want to mobilize the entire Buddhist community in their favor by igniting the anti-Muslim narrative. Similarly, the military also wants to preserve communal tension so that unified anti-military protest never gets momentum. These shared goals foster cooperation and support between the military and the Buddhist extremists. During the military rule, laypeople were not allowed to do processions on the street while the military not only allowed but also supported the Buddhist extremists to run the procession and campaigns against the Muslims (Contributor-11, Personal Communication, September-4, 2019).

Due to prolonged military rule, Myanmar military has deeply rooted its power grip across the nation. Therefore, the military wanted to remain in power probably for two reasons; one is to deter any initiative for the accountability of past genocidal acts by the security forces, and second, is to ensure the corporate financial interests of the military (Selth, 2018,pp-5-9). For remaining in state power, the military needs the 
support of the citizens, which is always critical for any military government. Therefore, to bring the people's support in their favor, the Myanmar military relies on Buddhist extremist groups, who have significant influence over the majority population. On the other hand, Buddhist extremist groups historically enjoy unchallenged absolute power over the majority Buddhist population because Buddhism has substantial control over Myanmar society. Ironically, prominent Buddhist leaders adopted the radical ideology of mono-ethnic religious nationalism and have developed significant intolerance about other religions. As the Buddhist extremist leaders realized that the moderate Buddhist monks often challenge their radical visions, therefore, they wanted to create conflict-supporting narrative against the Muslim minority Rohingyas, which helped them to unite all extremist powers in their favor.

The radical Buddhist leaders realized that the military needs their support to gain popular support. In turn, they need the help of the military to restrain the influence of other religions in Myanmar. Myanmar government holds the constitutional powers and capable of making any policy and law. Therefore, the military and Buddhist extremist groups both need the government's support to annihilate the Rohingyas by promulgating discriminatory policies and laws. On the other hand, the Myanmar government wanted to remain in power for which they need the cooperation of Buddhist religious leaders. The government also wanted to establish its credibility in ruling the country, which was not possible if the military does not cooperate and support the government because the military not only controls the parliament and local governments but also controls the 
economy and politics of Myanmar. The government for its very existence, need to support the military and the Buddhist extremist groups.

So, we can find that the top three stakeholders in Myanmar Rohingya conflict are mutually supported by each other, and all of them unite on the common issue of antiRohingya narrative. To understand the base of such cooperation between these stakeholders, we also need to analyze the socio-political context of Myanmar. Myanmar is a society where religion is a prime social factor than anything else. In such a society, if the military wants to remain in state power, they need to prove them as indispensable for Buddhism. Therefore, the Myanmar military adopted the role of a custodian of Buddhism. In this regard, the first challenge was to clarify their role as custodian of Buddhism. The military leadership created a roadmap to portray themselves as custodians of Buddhism. First, they planned to project some threats against the legacy of Buddhism, and second, they wanted to act violently against that threat. To propagate the so-called threat, they utilized the Buddhist extremist leaders in determining the threats against Buddhism in Myanmar. The military-inspired the Buddhist extremist leaders to identify the Muslim minority Rohingyas as the threat to Buddhist legacy in Myanmar. Then the military took charge to neutralize that threat. Therefore, so long the threat to Buddhist heritage remains in Myanmar, the mutual support between the military and Buddhist extremist groups will stay strong, and together they will continue to share the state power.

The Rohingyas being the victim of the above-mentioned power politics are unable to protect them from suppression and violence because of the considerable power gap and the absence of the rule of law. More so, due to the coordinated and institutionalized anti- 
Rohingya campaign by Buddhist extremists, sympathy is eroded from the minds of the majority of the Myanmar population (Fink, 2019, p.241). Therefore, much protest was not observed by civil society when the mass human rights violations and the genocide took place in 2017. Not only the Myanmar locals, but the international community also responded inadequately to stop the genocide. Ironically, after experiencing a sequel of violence, the Rohingyas failed to gain any tangible support from the international community to resolve the conflict or to end the oppression. The reason for such failure might be the lack of freedom of speech, heavy restrictions on political acts, the geopolitical interest of the superpowers, and constant state surveillance on the Rohingya.

The rise of the religious xenophobia became a driving force for perpetuating the chronic communal violence in Myanmar. The Myanmar government, the military, and the Buddhist nationalists are steering the Buddhist nationalism for their gains. The integration of these three most powerful forces of Myanmar in a common cause created a single powerful entity for the anti-Muslim force. The massive power structure, the strong support base, and religious mandate from majority Buddhists for this single antiRohingya entity made it unstoppable and unquestionable. The military, by its power and capacity, became the slaying machine for this anti-Rohingya entity. As the military feels them more powerful due to the alignment with the government and the majority of the Buddhist community, the military commanders assume that they have the legitimacy to resort to some extreme actions towards the Rohingyas. From such understanding, the military, along with the Buddhist extremist groups, often adopted coercive measures to deal with the Rohingyas, and the government remained silent. 


\section{Chapter 10: The Impacts of Religious Nationalism on the Security Situations of the}

\section{South Asian Region}

\subsection{Buddhist Extremism in Myanmar and its Impacts on Neighboring Countries}

The rise of religious nationalism in Myanmar and its spillover impacts has greatly influenced the actions of nationalist groups in her neighboring countries. The interesting aspect of religious nationalism is that when the Buddhist extremist groups perpetrate violence on other religious groups, they never perceive the consequences on their own religious groups living in other countries as minority groups. They initiate a cycle of violence sometimes as part of a strategic move or as a random act without counting the consequences. When a particular religious majority group creates a narrative of "Othering," then it divides the society deeply. The religious nationalism promotes radicalism, which often leads to violence and thus creates mistrust, fear, and division. Such a division in society poses a serious threat to the country's law and order, which ultimately contributes to destabilizing the security situation of a region.

The violent inter-ethnic religious tension in Myanmar created some spillover impacts over her neighbors. The apparent rise of religious nationalism in Myanmar has contributed heavily to boost the growth of religious nationalism in other parts of South Asian and Southeast Asian regions, like Sri Lanka, India, Bangladesh, Thailand, and China. It is quite evident that the Buddhist extremists of Myanmar have only concentrated on the geographical boundary of Myanmar, but also extended their vision regionally. The violence over the Muslim minorities in Myanmar by Buddhist extremists has created a twofold impact on her neighbors. In the Buddhist or Hindu majority 
countries, a sharp rise of anti-Muslim narrative and religious violence over the Muslims are observed. There are numerous evidence that the extremist Buddhist groups in Myanmar contributed in many ways to the rise of Islamophobia in the neighboring countries, which gave rise to communal violence in many parts of Asia. On the other hand, in the Muslim majority countries, the Rohingya issue generated much agitation against the Buddhists and other religions, and some of them led to communal violence.

The rise of Buddhist nationalism in Myanmar has created huge resentment in the minds of the Muslims in Myanmar as well as the Muslims living in Bangladesh, Pakistan, India, Thailand, and Sri Lanka who have the potential to react violently. These situations are likely to lead to the destabilization of the peace and stability of the South Asian region. The deterioration of the security situation in this region is a matter of grave concern for many reasons. First, due to poor socio-economic conditions the region is vulnerable to exploitation by the religious extremists, second, due to the lack of education and social awareness, people of this region often get wrongly motivated in the name of religion and participate in communal violence, and third, the weak social safety net and fragile social service structures are likely to collapse in the event of any serious humanitarian disaster. According to the UNHCR, the Rohingya refugee crisis already turned to a severe humanitarian disaster. The impacts of growing religious nationalism in Myanmar on her neighbors are evaluated in the subsequent paragraphs.

\subsection{The Influx of Rohingya Refugees and Security Threats for Bangladesh}

Bangladesh is the worst affected country due to the xenophobic rise in Myanmar. 
Because of the issue of the refugees, the diplomatic relationship between Bangladesh and Myanmar has deteriorated in recent years. In the last thirty years, the relationship was frequently affected by the 'push-in' and 'push back' of Rohingya refugees. In 2012, approximately 200,000 Rohingyas became refugees and sheltered in Bangladesh (Human Rights Watch, 2014). The relationship between both the countries had deteriorated further since August 2017, when more than 600,000 Rohingyas moved to Bangladesh to save their lives from the violence perpetrated by the Myanmar military and the Buddhist extremist groups (United Nations Human Rights Council, 2018). The vast number of refugees created additional pressure on highly populated Bangladesh and the socioeconomic conditions of her citizens. The Myanmar military crackdown on Rohingyas in August 2017 generated much tension between the border guard forces of both countries. The influx of the refugees in bulk raises a security concern for Bangladesh because when the borders need to be open for humanitarian consideration, it becomes very hard for the border controlling authorities to establish controlled checking procedures. Such an inability to effective border control leaves the probability of foreign terrorists entering Bangladesh to destabilize the prevailing security situation.

Bangladesh is the residence of 146 million Muslims, which is more than $90 \%$ of her population. Therefore, it was a challenge for the Bangladesh government to refrain the large Muslim population from retaliation on the Buddhist minority communities when the Muslim minority Rohingyas were killed, raped, and evicted from Myanmar. There was huge resentment among the Muslims in Bangladesh, and many Islamic organizations rallied on the street, condemning the genocide conducted by Myanmar. Religion is such 
a sensitive aspect of human life that it does not require any direct involvement or communication between the same religious groups to be mutually sympathetic. In the event of any communal violence in India toward the Muslims, there were immediate repercussions inside Bangladesh. On a few occasions, Hindu minorities living in Bangladesh had to suffer the consequences. Therefore, despite not having any regular relationship among the Rohingyas in Myanmar and the Muslims living in Bangladesh, the Islamic organizations and lay Muslims feel it their sacred responsibility to show sympathy and offer support to the Muslim minority Rohingyas. Due to the secular mindset of dominant liberal Muslims in Bangladeshi society, Islamic organizations could not utilize the Rohingya issue to destabilize the country's law and order. However, this kind of issue remains an internal security threat for the government.

Bangladesh, since it is a highly populated Muslim country, has always remained vulnerable to the threats of Islamic extremist groups. The inferior economic condition, poverty, and lack of education make its population subject to exploitation by the Islamic extremists. In recent years the education rate has improved, and the country turned into a middle-income country, yet unemployment and illiteracy prevail in some parts of the rural population mostly. In the last few decades, the Middle East and Pakistan-based Islamic extremist groups tried in many ways to radicalize the Muslim community in Bangladesh but failed due to the long-practiced secular heritage of Bangladeshi people. Due to the influx of Rohingya refugees, there is a golden opportunity for the Islamic extremist groups to recruit their activists from the refugees who are desperately seeking means to survive. Bangladesh, with its limited resources, is certainly not capable of 
managing vast numbers of refugees and thus requires proper involvement of the international community and their sustained support. If the international community fails to provide credible support to the refugees and arrange their immediate repartition, then the large number of Rohingya refugees will be vulnerable to exploitation by religious extremists. Such vulnerability of the refugees may seriously destabilize the security of the South Asian region.

\subsection{Rise of Buddhist Nationalism and Ongoing Violence in Sri Lanka}

Sri Lanka is the most impacted by religious violence in recent days. Following the violent conflict between Buddhists and the Rohingyas in Myanmar, religious tension has prevailed all over Sri Lanka since November 2017, which led to communal violence in southern Sri Lanka. Ten vehicles, 62 houses, and business centers were attacked; the Muslims owned the majority of them. The Sri Lankan government had to impose evening curfew to deal with the situation. The rise of Buddhist extremism in Sri Lanka is not an isolated event; the Buddhist nationalist groups of Myanmar have patronized the Buddhist radical groups of Sri Lanka. The prominent Buddhist extremist group of Sri Lanka is known as 'Bodu Bala Sena,' led by Kirima Wimalajothi, has posed a serious challenge to the Sri Lankan secular society (Schonthal and Walton, 2016, pp.81-115). The visit of radical Buddhist Monks Aswin Wirathu to Sri Lanka in 2014 and his address to Buddhist monks were mainly to propagate Islamophobia and create a regional platform for the anti-Muslim narrative. In his speech, Aswin Wirathu urged the monks to fight against the Muslims, mentioning the Muslims as a threat to Buddhism (Schonthal, 2016). The Buddhist nationalism in Sri Lanka has taken its extreme form. They are not only 
propagating the anti-Muslim narrative, but they have also targeted the Christian population (7.9\% of the total population) living in Sri Lanka. In 2014, the members of Bodu Bala Sena stormed the Holy Family church in Kandy district (Gravers, 2015, p.16). The impacts of such cooperation of Buddhist extremist groups are enormous in Sri Lankan society, and the violence carried out by the Buddhist extremists on the Muslims in 2017 is the outcome of such impacts.

The rise of religious nationalism in Sri Lanka generated a cycle of violence and created a favorable condition for the different religious extremist groups to operate. The communal violence of 2017 was a clear indication of the level of mistrust created among the Buddhists and the Muslims, but the government did not address the issue adequately. The recent bomb blasts in Sri Lankan churches and hotels show the threat the country bears from the religious nationalists. On April 21, 2019, during the Easter Sunday celebration, three churches and four luxurious hotels in Sri Lanka were hit by a series of coordinated suicide bombing. The death toll raised to 258 , including 46 foreign nationals, three police officers, and around 500 people were injured (Bruni, 2019). Such a terrorist attack in Sri Lanka destabilizes the country's security as well as the security of the South Asian region.

\subsection{The Rise of Ultra Hindu Nationalism in India}

The xenophobic rise in Myanmar has significantly influenced the political situation in India and helped to boost ultra-Hindu nationalism in India. The sectarian violence against the Muslim minority Rohingyas by the Myanmar military and Buddhist 
extremist groups compelled them to take shelter in neighboring countries as refugees. A significant number of refugees moved to India for shelter, which reignited the Hindu nationalism and their anti-Muslim narrative and thus created political pressure on the government to push the refugees out of the Indian border. The government, on some occasions, expelled the refugees instead of providing them humanitarian support. On the other hand, the government action regarding the refugees disheartened the liberal Hindu's and the Muslim sentiment in India.

The Hindu nationalist groups view the Muslims in India as the "Others" who do not necessarily belong to the true identity of India. Since the ultra-Hindu nationalist party Bharatiya Janata Party (BJP) came to power in India, the anti-Muslim narrative gained much momentum. The Hindu nationalist groups not only demean Muslims through hate speeches and social media campaigns, but they also force the government to enact antiMuslim policies. Accordingly, in 2018, the Indian immigration authority took the initiative to identify the illegal immigrants and deport them, which eventually targeted Muslims who had lived for decades in India, many for generations, and some who held government positions. According to the policy, illegal immigrants who are Muslims will be deported only, not the believers of other religions. The government initiative was allegedly part of the anti-Muslim campaign of ultra-Hindu nationalists backed by the ruling party BJP. The government initiative to enact policies that target the Muslims will create further resentment among the Muslims, which will boost the communal between the Hindus and the Muslims. Many political scholars in India view the rise of Hindu nationalism as a threat to the socio-political stability of India, which threatens the 
national security of India as well and also the regional security of the South Asian region.

There was lots of criticism throughout the first term of Indian Prime Minister Mr. Narendra Modi's government for human rights violations against the religious minority groups, the promulgation of discriminatory laws, and favoring the religious extremist groups. The controversial initiative of present BJP led government is the National Register of Citizens (NRC), which aimed to strip the citizenship status of religious minority groups. The NRC is a list of people who need to verify that they were living in India before March 24, 1971, the day before the independence of Bangladesh from Pakistan (Dutta, 2018). It is reported that the NRC is strictly implemented mainly in the Muslim populated provinces of India, like Asam and West Bengal, to reduce the number of Muslims living in India. The implementation of the NRC is widely viewed in India as a religious stance, and it is on the top priority of the Hindu Nationalist party, BJP. However, Indian people have elected the ultra-nationalist Hindu nationalist party, BJP, for the $2^{\text {nd }}$ term to rule the country. This recent election result signifies the rising trend of religious nationalism that presently exists in India.

\subsection{The rise of Islamophobia in Other Neighboring Countries of Myanmar}

The rise of religious nationalism in Myanmar has created significant spillover impacts on her other neighboring countries, like Thailand and China. For a long, the Buddhist nationalist groups in Thailand and China have created an Anti-Muslim narrative, which was boosted recently following the Rohingya Muslim crackdown in Myanmar. There are more than 20 million Muslims live in China who is subject to state- 
sponsored negative media coverage of stereotyping Islam as a radical group (Luqiu and Yand, 2018, pp. 598-619). The millions of Muslims in Uighurs and Xinjiang are experiencing inhuman treatment by the state and the Buddhist religious communities. In 2017, the Chinese government enacted a law to implement the ban on Burqas, veils, and beards, which created serious resentment among Muslims. Further resentment among the large Muslim community may flare up at any moment, which may lead to violent communal conflict. There is also a growing anti-Muslim sentiment in Southern Thailand, which often leads to Buddhist-Muslim sectarian conflict.

The anti-Muslim narrative in Thailand has gained significant momentum in the last five years. The worldwide rise of Islamophobia has also influenced Thai society to adopt the anti-Muslim narrative. Though the experts' view that there is no substantial indication about the rise of Islamic terrorism in the Southeast Asian region. The hate propagates against the Muslims indicate the growing prominence of religious extremism, which has become a significant challenge for the governments in the region. The violence on Rohingyas failed to generate much sympathy from the people and governments in Southeast Asia because of anti-Muslim perception that overshadowed the humanitarian concern (Pathan, Tuansiri \& Koma, 2018). Out of Thailand's 61 million populations, approximately 4 million are Muslims, who mostly live in the Southern border province. The rising Buddhist nationalists with their anti-Muslim narratives recently opposed the construction of any new mosques and a halal food production factory in the region. Even the teacher of public schools protested against the elementary school students wearing Hijab (Pathan, Tuansiri, Koma 2018). These kinds of prevailing 
communal tensions may further escalate to violent conflict, which may destabilize the country's law and order situation and may pose a threat to regional stability. 


\section{Chapter 11: Concluding Remarks and Possible Ways Forward: Recommended Directives for Resolution}

\subsection{Concluding Remarks on Findings}

Throughout this study, the critical aspect that came up is the complex and seamless interrelation between religion and nationalism in Myanmar. Over the decades under the military sponsorship, some segments of the Buddhist community became extensively radicalized and established the most dominant Buddhist authority in Myanmar. While promoting the anti-Muslim narrative, these extremist Buddhist communities deviated from the traditional teachings and role of Buddhism and entangled religion with power politics. They have adopted violence as a means to attain their religious and political goals. To achieve the political goal, the extremist Buddhist monks compromised with the illegitimate military rule overlooking the massive human rights abuses and continuous denial of the citizens' rights in Myanmar.

This thesis has emphasized the ongoing phenomenon of using Buddhism for xenophobic purposes in Myanmar by mobilizing the Buddhist population together centered on collective identity in religion. Buddhist extremists also created common fears

and insecurities by portraying the Muslim minorities as a threat to the Buddhist legacy for uniting the Buddhist population. The Buddhist nationalists misinterpreted religious sermons, symbols, and teachings to attract people and to mobilize them towards a narrow path of Buddhist nationalism. Also, the extremist groups shrewdly linked Buddhism as the key to Burmese national identity to achieve national purity. In this process, they have undermined the traditional role of Buddhism, and it's teaching of compassion and 
empathy, which immensely tarnished the peaceful image of Buddhism. Throughout this process of xenophobic rise, the Myanmar military has successfully utilized the influence of Buddhism on Myanmar society in its favor to legitimize their illegitimate rule.

One thing that needs to be understood clearly is, the Myanmar military is unlike the traditional military of any other country. They have a deep influence in every sphere of the socio-political and economic aspects of Myanmar. The Myanmar military is the only military in the world that constitutionally holds $25 \%$ of seats in the national parliament. For a considerable period, the Myanmar military has been dealing with the political and economic power of the country. Therefore, they are less interested in distancing themselves from political power.

Moreover, they are the controlling force for the entire legislative setup in Myanmar because the military officers also lead many semi-government offices. Even the military generals lead a few ministries of Myanmar. The local government systems in some areas are tied with military installations. The military has tightly integrated its functions with the local government system to control the root level state affairs, which have made it challenging to democratize the society. In the process of doing so, they have developed a mutual relationship with the Buddhist extremist groups, who aspire to be a part of state power in Myanmar.

The military has so far succeeded in legitimizing its rule by boosting the rise of religious nationalism in Myanmar. By positioning itself as the guardian of the Buddhist identity of the nation, the military validates its central role in Myanmar politics and 
Myanmar society. But one of the negative consequences is that the military, through the same process of legitimization, can self-justify the actions of challenging, confronting, and eventually attacking the identity groups that are not Buddhist. Such justification sets the stage for the military and Buddhist nationalists to target the Muslim minority Rohingyas for ethnic cleansing in 2017.

The Buddhist extremist groups are inspired by the historical legacy of Buddhism that had been close to state power for many centuries. Both the military and the Buddhist monks have adopted the anti-Muslim narrative that is capable of moving the laypeople through socio-political and religious motivation. Based on the anti-Muslim narrative, both the military and the Buddhist extremists created an environment of fear. They propagate the fear of losing the religious legacy of Buddhism and threat to national security, which mobilized the majority Buddhists to rally behind them. In this situation the Buddhist extremists targeted the Rohingyas as a scapegoat in achieving their interests. Even though the Rohingyas are living in Myanmar for many centuries and few were integrated into policymaking, the Rohingyas began to live under difficult living conditions since the start of military rule. Both the Buddhist extremists and the military established a cycle of expectation; the Buddhist extremists want the military to support them to fight against Rohingya. By doing so, they want to portray themselves as the guardian of Buddhism in Myanmar. On the other hand, the military has entrenched their power by propagating the exclusive Buddhist identity of the society through a close alliance with the nationalist Buddhist monks. 
The military junta in Myanmar realized it would be easier for them to retain their power over a destabilized society rather than that of a stable society. They understood that the Rohingya issue was historically the most controversial in Myanmar society, and the Buddhist community always retained their reservations about the Rohingyas. The Myanmar military pragmatically coopted this issue to utilize it for gaining the faith of the majority Buddhist community who see Rohingyas as separatist and a threat to their religious dominance. On the other hand, the elected civil government and political parties understand the impacts of military influences all over the country, which compel them to consider the military as a partner for state power, not merely as a government organ. That's the reality in Myanmar politics. In the context of such power inequality, without the support of the military and religious clerics, it is hard for any government to survive. Global acceptance of Myanmar's present version of democracy and the economic interests of China and the USA further narrowed the scopes for effective communication between the groups involved in the Rohingya issue for a meaningful resolution of the conflict.

Myanmar civil society is living under constant terror. The civil society is highly impacted by religious nationalism and prolonged military rule. Therefore, civil society is not capable of playing the traditional role as represented by a civil society elsewhere. The civil society has been experiencing violence and intimidation of the military since 1962 . For a long time, they have been denied freedom in many spheres of life, including freedom of expression. People often become subject to military surveillance and interference. Press and the media experience strict censorship while voicing people's 
opinions and ideas. The government has increasingly applied its overly broad and vaguely worded laws to detain, arrest, and imprison individuals for expressing their views on social media and taking part in nonviolent processions. Activists and journalists experienced enhanced scrutiny, heavy restrictions on media, shadowing, pressures, and harassment by the military or other law enforcing agencies. The increased surveillance of journalists created a fearful environment, which negatively impacted the country's media. Therefore, public participation in the socio-political issues became challenging, and thus government policies and actions hardly reflect people's will. More so, the huge power gap between government institutions and civil society created barriers for meaningful dialogue and other forms of communication.

In the context of Myanmar conflict, where massive social injustice and power inequalities are prevailing, the opportunities for meaningful intergroup dialogues are often minimum. Mutually enhancing interaction between unequal powers is always challenging (Anastasiou, 2007, p.63). When the military alongside the government enjoys absolute power of controlling the socio-economic and political sectors, and when the Buddhist monks mutually support them, then it becomes challenging to make them listen to the voices of minorities when it comes to injustices. More so, the intense surveillance and censorship on the press and media add barriers for civil societies, which made them unable to stand beside the minority groups and voice against discrimination and social injustices. Thus, in a massive institutional framework of systematic oppression, the Rohingyas find it very hard to empower themselves by gaining support and sympathy from both internal and external sources. 


\subsection{Possible Ways Forward}

As the prevailing human rights situation has turned to a humanitarian disaster, outside help required for bringing a constructive process that might be able to bring some way forward for resolving the conflict. The Rohingya crisis demands three-pronged attention: one, take immediate measures to initiate a meaningful dialogue with the donor countries, the UN, and the Bangladesh government to develop a roadmap to support the Rohingya refugees and ensure minimum living standard in the refugee camps. Two, tangible steps should be taken to exert diplomatic pressure on the Myanmar government to conform with the Kofi Anan Commission's recommendations and ensure a secure environment in the Rakhine province for the safe return of the refugees. Three, efforts should be taken to re-establish democratic norms, accountability, and communal harmony in Myanmar society. The reconciliation process should start immediately. In all these processes, the UN should take necessary steps to oversee the prevailing situation in the Rakhine state and ensure that the Myanmar government agrees to make appropriate arrangements to accommodate the Rohingyas in mainstream society with their rights fully recognized. In this regard, the Rohingya leadership should be consulted for any future steps that might be taken by the international community.

According to the findings of the recent UN Independent Fact-Finding Mission Report on Myanmar, the Myanmar government failed to reform or amend the hostile policies regarding the Rohingyas, which led to the denial of their citizenship rights, dehumanization, and difficult living conditions. The government has not taken any credible measures to stop hate speeches against the Rohingyas, the continuation of ethnic 
cleansing, mass human rights violations, and evictions from their own houses. The commission further asserted that the Myanmar government strengthened the conditions in the Rakhine state that led to ethnic cleansing. Therefore, there prevails a high risk of the recurrence of communal violence and genocidal acts. The commission also claimed that the Myanmar government yet had not shown any intent to stop, prevent, or investigate the genocidal acts that are perpetrated against the Rohingyas. In the end, the commission opined that considering the prevailing hostile environment maintained by the Myanmar government and its military, the voluntary, dignified and safe return of about one million Rohingyas would not be possible in the immediate future. Due to the stubborn attitude and non-cooperation of the Myanmar government with the international community, the mission is not even sure when the safe return of the Rohingyas can take place (United Nations Human Rights Council, 2019). In light of the facts mentioned above, it is quite clear that unless reasonable diplomatic pressure is exerted on the Myanmar government and its military, the situation will further worsen.

Any comprehensive and credible initiative by the $\mathrm{UN}$ and the world community could tip the balance of power in the Myanmar Rohingya conflict, but unfortunately, that has not happened. Though numerous examples of such international initiatives are evident in the recent geopolitical context, the international community has shown considerable reluctance to invest in the Myanmar conflict. On the other hand, unconstitutional responses of the international community made the Rohingya Muslim minorities less powerful and more frustrated. Such a lack of confidence and mistrust among the low power groups will make them susceptible to any initiative for dialogue 
unless sensible, honest approaches are not in vogue to resolve the conflict. The international community should exert pressure on the Myanmar government to implement the Kofi Annan Commission's recommendations at priority basis. However, the Anan commission report was largely rejected by the Buddhist extremist groups first, and eventually by the Myanmar government, blaming the commission for supporting the Rohingyas. While interviewing the Rohingyas, many of them mentioned that they do not want any monetary help from the international community; they want their rights back and want to live in peace.

The experiences of the Buddhists and the Muslims are diverse and complex. Both sides developed a hostile relationship, and communication between them has been suspended. It is necessary to identify the existing communication challenges among the groups to move towards the resolution. Therefore, intergroup interaction between different groups needs to be initiated at multiple levels involving people from all spheres of society. The potential grounds for the interactions between different groups of Myanmar need to be identified and analyzed for possible outcomes through the interactions. Starting from the cultural interactions and exploring the education system, religious festivals, sports, and many other potential sectors for communication might be useful. It is essential to make sure that no initiatives are confined only to specific groups of people. The efforts should welcome teachers, farmers, community leaders, students, social workers, government employees, journalists, writers, and anyone who has the opportunity and potentiality to contribute to the resolution process. The dialogues between groups should start from the root level and then reach to the top, focusing on 
expanding the knowledge about each other, opening up the information of each other, and exploring the visions of each other. The dialogue should also clarify the facts and assumptions that each side perceives each other. A deep understanding of each other will help to eliminate suspicion and mistrust; assisting each group in restoring trust within groups.

The social dialogues need to be initiated countrywide by civil society. The UN, International NGOs, and peace groups can step in to assist the Myanmar civil society in providing moral and logistic support to initiate such dialogues. Myanmar civil society, academia, and scholars might need to build the structure to hold a countrywide dialogue. In these processes, the Rohingyas should ensure that ARSA suspends its operation, and the community should distance themselves from any armed activities. The UN country team and the diplomatic core working in Myanmar should take the lead role to mediate between the Buddhists and the Muslims living in Myanmar. Liberal Buddhist communities need to be included alongside the civil society to foster meaningful conversations between different groups on social inclusion and social justice for the minority groups living in Myanmar. It is essential to introduce intercultural training at an appropriate level to foster cohesion among the majority Buddhists and other religious minorities. The cross-cultural training may help both sides to understand each side's perspectives from cultural lenses. The study of commonalities and differences in food habits, dresses, and traditions will enable the groups to realize the sensitivity of each other thus becomes respectful to diversities.

It is essential to introduce peace education in schools and at the community level 
to instill tolerance, empathy, and compassion towards each other. For children and youths, peace education can be integrated with the school curriculum. For elders, peace education can be imparted through workshops, seminars, town hall meetings, and community clubs. Peace education should include aspects of cross-cultural communication, restorative justice, diversity, and gender equality. Peace education should also focus on nonviolence communication and non-violence movements across the world. Peace education should also focus on nonviolence communication and nonviolence movements across the globe. All ethnic minority groups should also have access to peace education.

Myanmar should utilize its economic and cultural potentiality through a massive socio-political reform to achieve its democratic vision. Instead of being isolated from the international community, the Myanmar government, along with its citizens, should work to introduce democracy at the grassroots level of people's life. There is an urgent need to resume the function of democratic institutions and the social establishments, which were crippled during the prolonged military rule. Otherwise, in the future, it will be difficult to find any functional democratic institution in Myanmar. The citizens should not be kept deprived of interacting with global societies under the shadow of military surveillance. It is expected that the Buddhist communities in Myanmar soon will separate themselves from the influence of the Buddhist radical groups and will be able to uphold the traditional peaceful values of Buddhism.

It is quite evident that without the initiatives of the international community, the intergroup dialogue will never be possible between the Myanmar governments, the 
military, Buddhist extremist groups, civil societies, and the Rohingya minorities. Historically, the military and the Buddhist majority groups have never participated nor have been interested in any mediated dialogue. Therefore, third-party intervention to mediate the conflict is a necessity in the Myanmar context. That third party might be the UN or the international community who will be able to impose effective sanctions on Myanmar military and the government to comply with international human rights standards while dealing with the minorities. Unless the Rohingyas are given back their legal status, they will remain powerless and stateless, which will further complicate the crisis. More and more joint initiatives by international organizations and the civil society to hold dialogues between the communities of the Buddhist majority and Rohingya minorities can create a safe space for working together to resolve the conflict. Scholars from both sides can also engage in the reconciliation process by sharing the experiences of both sides of the conflict to help each side in healing the wounds of communal violence. The international community needs to come forward to help the Myanmar government and Rohingyas to hold dialogues in safe places out of Myanmar to resolve the conflict.

The Rohingyas need to be empowered by providing legal and expert support so that they can effectively communicate their concerns and experiences about the conflict. Rohingya minorities also need to be supported to meet their basic needs, and they should be made aware of the rights so that they are able to report any discrimination and human rights violations appropriately. The access to voting rights might empower the minority Rohingyas to a greater extent. There is also a need to enable the liberal civil societies in 
Myanmar so that they can raise their voice against institutionalized, systematic oppression against minorities, and call for ending social injustice. When the civil society is strengthened, it creates a space for intergroup dialogues between Buddhists and the Rohingyas. For empowering civil society to function effectively, the freedom of press and media and social justice needs to be ensured. In this regard, the international community may work with the Myanmar government utilizing diplomatic tools to enforce the rule of law and to ensure human rights for all the citizens of Myanmar.

We need to ask the question of why the Myanmar government and military will comply with the international community's expectations. What will they get by stepping out of their positions and benefits? Especially when the military is worried about their fate due to their involvement in the past human rights violations. The fear prevails among the military men that if the military influence diminishes, they might be subject to trials and judicial procedures for their past crimes, which often motivate them to remain at the center of state power. Any international approach to Myanmar conflict should integrate the answers to these questions. Therefore, an essential aspect of the possible resolution is the provision of certain incentives for the Myanmar government and the civil society of Myanmar for their compliance with the international human rights standard. The incentive might be in any form. Some can be in the form of lifting sanctions and bans, some in the form of international recognition, while others may be in monetary form, Etc.

For resolving the Rohingya conflict, we need to consider what should be done with the religious nationalism? How can the flame of religious nationalism be defused? There should be some credible steps to restore and highlight the traditional Buddhist 
liberal ideology. The voices of the moderate Buddhist need to be included to project the peaceful nature of Buddhism. Support needs to be provided to the liberal Buddhists to facilitate the conversation with the majority Buddhist community, as well as similar discussion, should be initiated with other religions. Space should be created for the Buddhist nationalists to transform into a peaceful religious practice through religious and social motivation programs. International Buddhist and Muslim scholars should support the Buddhists and the Muslims in Myanmar to restore the peaceful traditional values of the respective religions.

It is essential to hinder the support base of the Buddhist extremist groups by motivating their followers. In the Rohingya conflict, there are only a few people from the military, government, and the extremist groups are the masterminds. The rests are the motivated mass people or the people who are the beneficiary of the conflict. It is quite evident that in most conflicts, not all the people participate in violence, knowing the consequences. Most people perpetrate violence to obey orders or to maintain their association, like the soldiers of the Myanmar military, some of who have committed genocidal acts in the name of safeguarding the religion; again, some of them just performed the routine job. The hope is that the people who are utilized or wrongly motivated are subject to be changed through awareness. These people need to be made aware of the negative impacts of religious nationalism. More so, as Buddhism plays a central role in Myanmar society, therefore, to diminish the radical views of Buddhism, the actual teachings of Buddhism need to be established in society. The traditional 
peaceful practice of Buddhism will help the community to come out from the vicious cycle of hate revenge and violence.

The UN Security Council should periodically monitor the human rights situation in Myanmar and propose to adopt feasible options to curtail the ongoing rise of religious nationalism in the South Asian and Southeast Asian regions. At the regional level, the Association of Southeast Nations (ASEAN) and the South Asian Association for Regional Cooperation (SAARC) should create a mandate to work together so that the member countries can cooperate with each other in curbing the religious nationalism, to diminish the security threats to the region. 


\section{Chapter 12: Conclusion}

The Myanmar Rohingya conflict has caused an enormous death toll and mass human rights violations. If the conflict cannot be resolved soon, a greater human catastrophe might occur than what is going on now. On the way to solve the Rohingya conflict, all parties must acknowledge the harm caused to the Rohingya community and hold them accountable who perpetrated the heinous crime. The most pragmatic approach to address the conflict would be to properly analyze every aspect of the conflict from each side's perspective. The experiences of the conflict by each side are real and need to be acknowledged and addressed accordingly. The Rohingya conflict is the outcome of mono-ethnic religious nationalism that surfaced from the prolonged period of undemocratic rule. The absence of the democratic norms in any society diminishes the social values and destroys the culture of accountability, which has happened in Myanmar.

The prolonged absence of democratic practices disregard for human rights, and the overwhelming influence of religion over the Myanmar society supported the xenophobic spirit in Myanmar. Myanmar society often placed the value of religious legacy over the citizens. Buddhism was raised to a level above Myanmar national identity, where the existence of other religions or faiths is considered as impure and undesirable. From such a nationalistic point of view, the Buddhist nationalist leaders identified Rohingyas as the significant threat for their religious legacy and accordingly unified all other stakeholders to attain a common goal of eliminating the Muslim minority Rohingyas. Such an anti-Muslim narrative and huge power asymmetry complicated the resolution process of the conflict. More so, due to lack of social mechanisms for 
accountability of social injustices made both the military and Buddhist majority leaders became less respectful about the rights of the minority groups. Again, the absence of limited voting rights of the ethnic minority groups made the political parties less caring or interested in preserving the rights of ethnic minority groups.

In the context of systematic, institutionalized discrimination, the scopes for intergroup communication became very limited. The immediate and long-term challenge is to build trust in the minds of the citizens regarding each other. In such a situation, international intervention for meaningful intergroup dialogues and holding the government and the military accountable for human rights violations might be useful. The appropriate credible interjection by the UN and the international community can bring a drastic change in the prevailing situation in Myanmar. However, as long as China and the USA support the Myanmar Regime due to their economic interest, it is doubtful how far the international community would be able to impose effective sanctions on Myanmar. A ray of light can be seen as the UN Security Council in early June 2019, urged the member states not to provide any support to Myanmar military to curtail its influence on the Myanmar government. Recently, in November 2019, the Gambia, a member state of the Organization of Islamic Cooperation (OIC), took a bold step to draft a claim to the International Court of Justice (ICJ) against Myanmar on the Rohingya issue. More and more similar initiatives need to be taken to address the ongoing Rohingya crisis, and the international community should rally behind those initiatives to ensure the conflict to end. 


\section{Chapter 13: Implications for Conflict Resolution and Future Research}

There are many important implications of my current study on the Rohingya crisis for resolution of the conflict or conflict transformation process. The study has analyzed the present socio-political and religious context of Myanmar and the root causes of the conflict. The study has following implications for conflict resolution process:

1. Communication challenges prevailing among the stakeholders, which need attention.

2. Huge power gap exist between the groups involved in the conflict that demands dialogue.

3. Still, Rohingyas are experiencing torture, eviction, and human rights violations in the Rakhine state.

4. Productive dialogues between conflicting groups are required on multiple issues.

5. Healing of Trauma and Trauma management for the large population of the Rohingyas are urgently required.

6. Effective mediation is required among the groups for an agreement to suspend the ongoing human rights violations in Rakhine state.

7. The storytelling may help people for healing and forgiveness.

8. There are scopes for international negotiation and mediation for the repatriation of the Rohingya refugees.

The current study has focused on unearthing the root causes of the rise of religious nationalism. However, the individualistic perspectives of extremism could not be analyzed due to the limited scope of the thesis. Therefore, further research should be 
conducted on why and how people adopt extremist perceptions? New research should also be conducted to identify the factors that can make a society more resilient against religious nationalism. 


\section{References}

Al-Jazeera (2019, March 18). An unholy Alliance: Monks and the Military in Myanmar. Retrieved from https://youtu.be/mF1GZ0O94qk.

Alter, Peter, (1994) Nationalism. London: Edward Arnold, Hodder Headline Group. http://www.amazon.com/NationalismPeterAlter/dp/0340600616/ref=sr_1_1?s=ga teway\&amp;ie=UTF8\&amp;qid=1285358811\&amp;sr=8-1

Anastasiou, H. (2007). The communication imperative in an era of globalization: Beyond Conflict-conditioned communication. Global Media Journal: Mediterranean Edition 2(1), 63-75.

Anastasiou, H. (2008). The broken olive branch: Nationalism, ethnic conflict, and the quest for peace in Cyprus (1st ed., Syracuse studies on peace and conflict resolution). Syracuse, N.Y.: Syracuse University Press.

Anderson, B. (1995) Imagined Communities: Reflections on the Origin and Spread of Nationalism, 2nd edn, New York: Verso. http://www.amazon.com/Imagined-Communities-Reflections OriginNationalism/dp/1844670864/ref=sr_1_1?s= gateway\&amp;ie=UTF8\&amp;qid=1285358865\&amp;sr=8-1

AP (2015, August 3). Myanmar's Anti-Muslim Monk Aswin Wirathu Joins hands with a Sri Lankan Group. Retrieved from https://youtu.be/MM0ZwphBbcc.

Arai, T. (2013). Toward a Buddhist theory of structural peace: Lessons from Burma/Myanmar. Paper presented at the Asia Pacific Peace Research Association (APPRA) Conference. Bangkok, Thailand. [Online] Available at: http://works.bepress.com/tatsushi_arai/54 (Accessed 1 April 2019).

Arendt, H. (1971). Thinking and moral considerations: A lecture. New York: Social Research.

Arendt, H. (1958). The human condition. Chicago: University of Chicago Press. Irreversibility and the power to forgive, pp. 236-247

Asian Development Bank. 30 April 2012. Asian development bank and Myanmar: Fact sheet (PDF). Retrieved 20 November 2012.

Bar-Tal, D., Oren, N., \& Nets-Zehngut, R. (2014). Sociopsychological analysis of conflict supporting narratives: A general framework. Journal of Peace Research, 51(5), 662-675. 
Beech H. (2013). The face of Buddhist terror', Time Magazine, 1 July. [Online] Available at: http://content.time.com/time/magazine/article/0,9171,2146000,00.html (Accessed 10 July 2019).

Bookbinder, A. (2013). “969: The strange numerological basis for Burma's religious Violence", the Atlantic. [Online] Available at: http://www.theatlantic.com/international/archive/2013/04/969-thestrangenumerological basis-for-burmas-religious-violence/274816/ (Accessed 11 July 2019).

Bruni, J. (2019). Sri Lankan Easter Attacks. SAGE, 1

Coates, E. (2013). Inter - religious violence in Myanmar: A security threat to Southeast Asia, RSIS Commentaries, June (117/2013), pp. 1-3.

Dostoyevsky, F., Garnett, Constance, \& Hubben, William. (1948). The grand inquisitor (Haddam House book). New York: Association Press.

Dutta, A. R. (2018). Political Destiny of Immigrants in Assam: National Register of Citizens. Economic and Political Weekly, 53(8).

Erich Fromm, (2001) The Fear of Freedom. Routledge; 2 edition.

Fink, C. (2009). Living silence in Burma: Surviving under military rule (2nd Ed.). Chiang Mai, Thailand: London; New York: Silkworm Books; Zed Books.

Foucault, M. (1978). The history of sexuality, New York: Pantheon Books.

Fox, J. (2003). Ethnoreligious Conflict in the Third World: The Role of Religion as a Cause of Conflict. Nationalism \&amp; Ethnic Politics, 9(1), 101-125.

Friedland, R. (2001). Religious nationalism and the problem of collective representation. Annual Review of Sociology, Vol. 27, 125-152.

Frydenlund, I. (2015, November). Are Myanmar's monks hindering democratization. In East Asia Forum (pp. 109-126).

Frydenlund, I. (2017). Religious liberty for whom? The Buddhist politics of religious freedom during Myanmar's transition to democracy. Nordic Journal of Human Rights, 35(1), 55-73.

Fuller, T. (2013). Extremism rises among Myanmar Buddhists. The New York Times, 20. 
Giddens, Anthony (1994) The Nation as Power Container in J. Hutchinson and A.D. Smith (eds) Nationalism, Oxford: Oxford University Press. ch. 6 pp. 34-36.

Global Firepower Index, (2019).

Gravers, M. (2013). Spiritual politics, political religion and religious freedom in Burma. The Review of Faith and International Affairs, Vol. 11 (2), pp. 46-54.

Gravers, M. (2015). Anti-Muslim Buddhist nationalism in Burma and Sri Lanka: Religious violence and globalized imaginaries of endangered identities. Contemporary Buddhism, 16(1), 1-27.

Guilloux, A. (2010). Myanmar: Analyzing problems of transition and intervention. Contemporary Politics, Vol. 16 (4), pp. 383-401.

Holliday, I. (2010). Ethnicity and democratization in Myanmar, Asian Journal of Political Science, Vol. 18 (2), pp. 111-128 [Online]. Available at: http://dx.doi.org/10.1080/02185377.2010.492975 (Accessed 01 June 2019).

Houtman, G. (1999). Mental culture in Burmese crisis politics. ILCAA Study of Languages and Cultures of Asia and Africa Monograph Series No. 33. Institute for the Study of Languages and Cultures of Asia and Africa. pp. 43-54. ISBN 978-487297-748-6.

Human Rights Watch. (2014). Burma: Scrap proposed discriminatory marriage law. [Online] Human Rights Watch. Retrieved from http://www.hrw.org/news/2014/03/24/burma-scrap-proposeddiscriminatorymarriage-law (Accessed 1 May 2019).

Hutchinson and A.D. Smith (eds) Nationalism, Oxford: Oxford University Press. http://www.amazon.com/Nationalism-Oxford-Readers-John

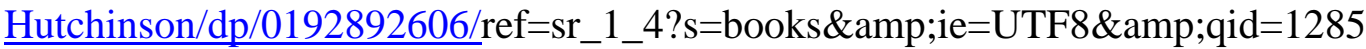
338776\&amp;sr=1-4.

Ibrahim, A. (2018). The Rohingyas : Inside Myanmar's hidden genocide. London: Hurst \& Company.

Jerryson, M. \& Juergensmeyer, M. (2010). Buddhist warfare. New York: Oxford University Press.

Johannessen, I. (2018). "One and a Half Human Beings": how Buddhist Monks Construct the Muslim Other in Myanmar (Master's thesis).

Jurgensmeyer, M. (2010). The global rise of religious nationalism. Australian Journal of International Affairs. 64 (3), 262-273. 
Kayshap, A. (2014). Dispatches: Denying freedom of choice in Burma.

Kawanami, H. (2009). Introduction: Power, authority, and contested hegemony in Burmese Myanmar religion. Asian Ethnology, 68(2), 177-183.

Kipgen, N. (2013). Conflict in Rakhine state in Myanmar: Rohingya Muslims' conundrum. Journal of Muslim Minority Affairs, 33(2), 298-310.

Kinnvall, C. (2002). Nationalism, religion and the search for chosen Traumas: Comparing Sikh and Hindu indentity constructions. Ethnicities, 2(1), pp.79-106.

Kinnvall, C. (2004). Globalization and religious nationalism: Self, identity and the search for ontological security. Political Psychology, 25(5), pp. 741-767.

Kyaw, T. A. (2013). Buddhist monk Wirathu leads violent national campaign against Myanmar's Muslims. [Online] Available at: http://www.globalpost.com/dispatches/globalpost-blogs/groundtruthburma/ buddhist-monk-wirathu-969-muslims-myanmar (Accessed: 20 January 2019).

Kyaw, N. N. (2014). Myanmar's rising buddhist nationalism: Impact on foreign investors.

Long, M. (2013). Dynamics of state, sangha and society in Myanmar: A closer look at the Rohingya issue. Asian Journal of Public Affairs, 6(1), pp.79-94.

Luqiu, L. R. \& Yang, F. (2018). Islamophobia in China: News coverage, stereotypes, and Chinese Muslims' perceptions of themselves and Islam. Asian Journal of Communication, 28(6), 598-619.

Marshall C. A. (2013). Special report: Myanmar gives official blessing to anti- Muslim Monks. Reuters. [Online] Available at: http://uk.res§uters.com/article/2013/06/27/us-myanmar-969specialreportidUSBRE95Q04720130627 (Accessed 21 January 2019).

Martin, M. F. (29 April 2010) Burma's 2010 elections: Implications of the new constitution and election laws. United States Congressional Research Service, Library of Congress, last accessed 5 July 2019.

Millington. A. (2017). The Independence, June 23, 2017.

Minority Rights Group International. World directory of minorities and indigenous peoples-Myanmar/Burma: Muslims and Rohingya, October 2017, retrieved from https://www.refworld.org/docid/49749cdcc.html [accessed 11 March 2019] 
Myanmar. (2014). In Encyclopedia Britannica Online. Retrieved from https://www.britannica.com/place/Myanmar. New Burma constitution published. BBC News. 9 April 2008. Retrieved 10 May 2008.

Nairn, Tom (1994) The Maladies of Development in J. Hutchinson and A.D. Smith (eds) Nationalism, Oxford: Oxford University Press. ch.11, 70-76

Nardin, T. (1996). The ethics of war and peace: Religious and secular perspectives. Princeton, N.J: Princeton University Press.

Paddock, R. (2017). Myanmar general's purge of Rohingya lifts his popular support. New York Times, 26.

Pthan, Don, Tuansiri, Ekkarin, Koma, \& Anwar (2018). Understanding anti-Islam sentiment in Thailand. Patane Forum, Thailand.

Schober, J. (2011). Modern Buddhist conjunctures in Myanmar. Honolulu: University of Hawai Press.

Schissler, M., Walton, M. J., \& Thi, P. P. (2017). Reconciling contradictions: Buddhist Muslim violence, narrative making and memory in Myanmar. Journal of Contemporary Asia, 47(3), 376-395.

Schonthal, B. (2016). Making the "Muslim other" in Myanmar and Sri Lanka. Islam and the state in Myanmar: Muslim-Buddhist religions and the politics of belonging. p.238.

Schonthal, B., \& Walton, M. J. (2016). The (New) Buddhist Nationalisms? Symmetries and Specificities in Sri Lanka and Myanmar. Contemporary Buddhism, 17(1), 81115.

Selth, A. (2018). Myanmar's armed forces and the Rohingya crisis.

Staub, E. (1989). The roots of evil: The origins of genocide and other group violence. Cambridge [England: Cambridge University Press. Ch. 16 The Cultural and Psychological Origins of War, pp. 249-260.

Steinberg, D.I. Arthur. M (2019). Myanmar In Encyclopedia Britannica Inc. Retrieved from https://www.britannica.com/place/Myanmar

The world factbook. (2014). Burma, Central Intelligence Agency. [Online] Available at: https://www.cia.gov/library/publications/the-world-factbook/geos/bm.html (Accessed 18 April 2019). 
Thompson, N. (2013). The 969 Movement and Burmese Anti-Muslim Nationalism in Context, Buddhist Peace Fellowship. [Online] Available at:

http://www.buddhistpeacefellowship.org/the-969-movement-and-burmese antimuslim- nationalism-in-context/ (Accessed 8 April 2019).

Times, M. (2016). State Sangha disowns committee for the protection of nationality and religion.

Tonkin, D. (2018). Political myths [Online]. Network Myanmar. Available: http://www.networkmyanmar.org/index.php/political-myths (accessed August 2019).

United Nations Human Rights Council. (2018), Report of international independent fact finding mission report on Myanmar. Retrieved from: https://www.ohchr.org/EN/HRBodies/HRC/MyanmarFFM/Pages/ReportoftheM anmarFFM.aspx

United Nations Human Rights Council. (2019), Report of International independent factfinding mission report on Myanmar. Retrieved from: https://www.ohchr.org/EN/HRBodies/HRC/MyanmarFFM/Pages/ReportHRC42t $\underline{\mathrm{hSession} . \operatorname{aspx}}$

United Nations Development Program. (2018). Human Development Indices and Indicators: 2018 Statistical Update. Retrieved 15 September 2018

Walton, M. J., McKay, M., \& Mar Mar Kyi, D. K. (2015). Women and Myanmar's "religious protection laws". The Review of Faith \& International Affairs, 13(4), 36-49.

Walton, M. J., \& Hayward, S. (2014). Contesting Buddhist narratives: Democratization, nationalism, and communal violence in Myanmar. Honolulu, HI: East-West Center.

Yegar, M. (1972). The Muslims of Burma.

Zawacki, B. (2012). Defining Myanmar's Rohingya problem. Hum. Rts. Brief, 20, 18. (Accessed 10 June 2019). 


\section{Appendix A- Questionnaire for Interview}

1. How long you have lived in Myanmar? You are from which part/state of Myanmar?

2. Which ethnic group do you belong to?

3. Do you have the citizenship of Myanmar?

4. Do your father and grandfather have the citizenship of Myanmar?

5. Have you studied in elementary/high school/college/university? Where have you studied, in public or private school? Have you experienced any restriction or challenge for your admission to public Scholl/ College/ University?

6. What is your current profession? Have you ever tried for a government job? Have you faced any challenges in applying for a government job? What percent of your community members are present in a government job? Is the percentage increase or it has decreased?

7. Do you own any business? Do you find any challenges or restrictions to do your business? What percent of your community members are involved in the business? Is the percentage increasing or it is decreasing?

8. Do you own any land? Have you bought it or you have inherited it? Do you find any challenge in managing your property?

9. Do you own a house, or you live in a rented house in Myanmar?

10. Have you ever voted in a national election? In the present parliament, how many members of Parliament are from your ethnic group? Has it increased or decreased in the last 20 years?

11. Do you face any challenges in expressing your minds in public? Can you travel to places freely within or outside of Myanmar? Do you think that you have adequate freedom of expression and freedom of movement? If not, why? Who restricts your freedom, and how?

12. Can you practice your religion freely in your locality? Do you face any restriction in practicing your religion? Do you anticipate any threat to your religious freedom?

13. Can you practice/celebrate your culture freely?

14. Can you freely participate in games and sports? How many members from your community could represent the national teams?

15. What is the state of healthcare in your state compared to other states of Myanmar? Can you avail of the public healthcare facility? If not, why and since when?

16. How is the marriage culture in your community? Is there any restriction in Myanmar on cross-cultural or cross-religion marriage? If yes, what is the restriction? Who regulates that restriction? Since when the restriction is imposed?

17. Have you ever experienced arrest/torture/abuse/eviction? If yes by whom, when, and why?

18. What is your opinion about democracy in Myanmar?

19. What is your opinion about the human rights state in Myanmar?

20. What you're your opinion about equity and social justice in Myanmar?

21. What is the development state of your community? Do you think that your community is equally developed like other communities of Myanmar?

22. Do you feel secure while living in Myanmar?

23. Do you anticipate any threat to your life and human rights? If yes, from whom and why?

24. Besides your community, is there any other community that are experiencing the similar situation of treat and discrimination?

25. How is the situation in Myanmar?

26. Who do you think is responsible for the present situation in Myanmar?

27. What you think are the main reasons for the present situation in Myanmar?

28. How do you think the international community may help to resolve the present crisis in Myanmar? 


\section{Appendix B- IRB Consent Form Form to Participate in Research (No Signature)}

Project Title: $\quad$ The Rise of Mono Ethnic Religious Nationalism in Myanmar and its Impacts on the Security Situation of the South Asian Region.

Researcher: S M Anisuz Zaman, Conflict Resolution, Portland State University

Researcher Contact: smzaman@pdx.edu] / 503-384-8625

You are being asked to take part in a research study. The box below shows the main facts you need to know about this research for you to think about when making a decision about if you want to join in. Carefully look over the information in this form and ask questions about anything you do not understand before you make your decision.

\section{Key Information for You to Consider}

- Voluntary Consent. You are being asked to volunteer for a research study. It is up to you whether you choose to involve yourself or not. There is no penalty if you choose not to join in or decide to stop.

- Purpose. The reasons for doing this research are the research is being conducted to identify the root causes of the Myanmar Rohingya conflict.

- Duration. It is expected that your part will last for about 45-60 minutes.

- Procedures and Activities. You will be asked to answer few questions related to your experience in living in Myanmar.

- Risks. Some of the possible risks or discomforts of taking part in this study include While answering my questions you might feel your emotion, you are allowed to take time as long as required to manage your emotions. I am a trained trauma manager; I will also help you in regulating your emotions.

- Benefits. Some of the benefits that you may expect include your voices will help in understanding the situation that Rohingya people are experiencing, which will help to identify the possible resolution pathways.

- Options. Participation is voluntary and the only alternative is to not participate.

What happens to the information collected?

Information collected from you for this research will be used to evaluate the prevailing situation in Myanmar. The information gather from you will be analyzed and evaluated in a manner that your experiences will be highlighted in the research outcome but your identity will not be included.

\section{How will I and my information be protected?}

We will take measures to protect your privacy including maintaining the confidentiality of your identifiable information. The appropriate measures will be taken to protect your identity. Your names, addresses and contact numbers will not be collected and shared with any other person. Despite taking steps to protect your privacy, we can never fully guarantee that your privacy will be protected.

To protect all of your personal information, we will ensure the confidentiality of your identifiable information. Your names, addresses and contacts will not be collected and shared with anyone and they will not appear in the research outcome. Despite these precautions, we can never fully guarantee that all your study information will not be revealed.

\section{What if I want to stop being in this research?}


You do not have to take part in this study, but if you do, you may stop at any time. You have the right to choose not to join in any study activity or completely stop your participation at any point without penalty or loss of benefits you would otherwise get. Your decision whether or not to take part in research will not affect your relationship with the researchers or Portland State University.

\section{Will it cost me money to take part in this research?}

There is no cost to taking part in this research, beyond your time.

\section{Will I be paid for taking part in this research?}

No. You will not be paid for taking part in this interview process.

\section{Who can answer my questions about this research?}

If you have questions or concerns, contact the research team at:

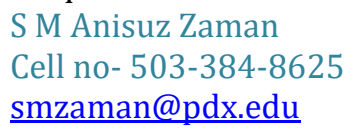

Who can I speak to about my rights as a research participant?

The Portland State University Institutional Review Board ("IRB") is overseeing this research. The IRB is a group of people who review research studies to make sure the rights and welfare of the people who take part in research are protected. The Office of Research Integrity is the office at Portland State University that supports the IRB. If you have questions about your rights, or wish to speak with someone other than the research team, you may contact:

Office of Research Integrity

PO Box 751

Portland, OR 97207-0751

Phone: (503) 725-5484

Toll Free: 1 (877) 480-4400

Email: hsrrc@pdx.edu

\section{Consent Statement}

I have had the chance to read and think about the information in this form. I have asked any questions I have, and I can make a decision about my participation. I understand that I can ask additional questions anytime while I take part in the research.

I agree to take part in this study

I do not agree to take part in this study 
Appendix C- Map of Myanmar

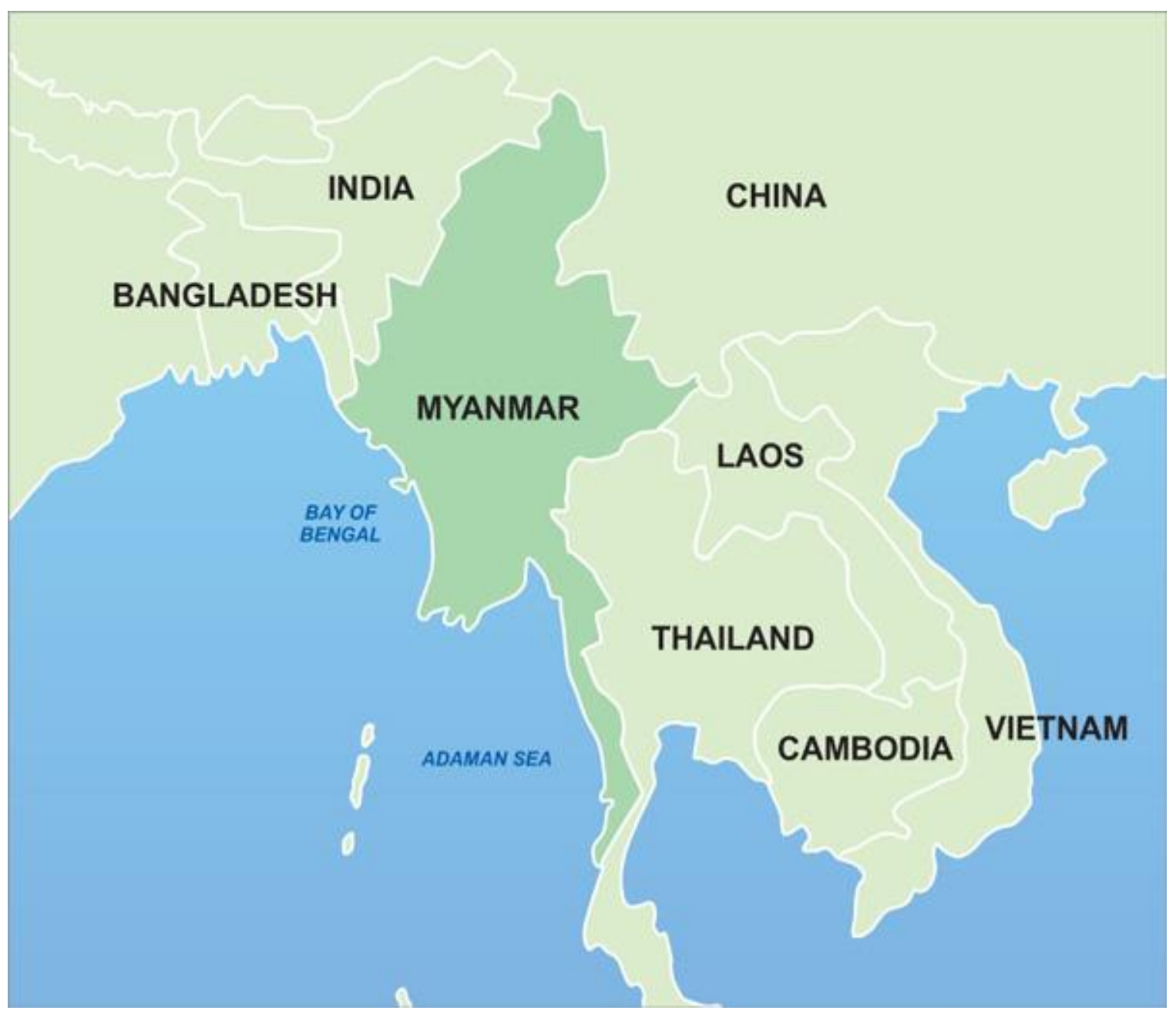

Sorce: Available at maps Myanmar:

https://maps-myanmar.com/myanmar-map-detail (Accessed 25June 2019) 
Appendix D- Map of Rakhine State

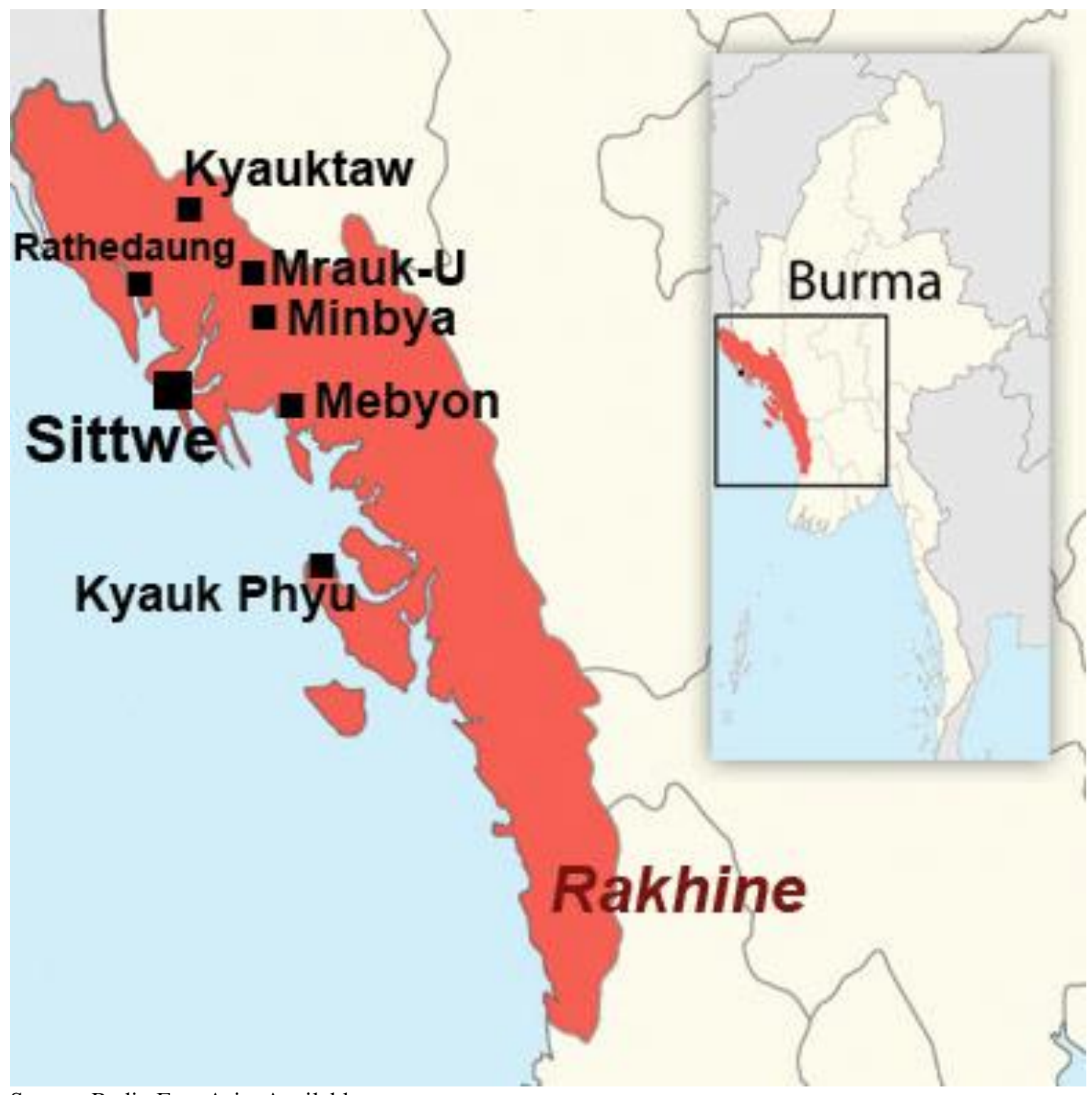

Source: Radio Free Asia. Available at: https://www.rfa.org/english/news/myanmar/violence-10252012182913.html (Accessed 25 June 2019) 